University of Louisville

ThinkIR: The University of Louisville's Institutional Repository

8-1947

\title{
A study of the academic success of veteran former probation students in the College of Arts and Sciences of the University of Louisville.
}

Rollin E. Godfrey

University of Louisville

Follow this and additional works at: https://ir.library.louisville.edu/etd

Part of the Education Commons

\section{Recommended Citation}

Godfrey, Rollin E., "A study of the academic success of veteran former probation students in the College of Arts and Sciences of the University of Louisville." (1947). Electronic Theses and Dissertations. Paper 1931.

https://doi.org/10.18297/etd/1931

This Master's Thesis is brought to you for free and open access by ThinkIR: The University of Louisville's Institutional Repository. It has been accepted for inclusion in Electronic Theses and Dissertations by an authorized administrator of ThinkIR: The University of Louisville's Institutional Repository. This title appears here courtesy of the author, who has retained all other copyrights. For more information, please contact thinkir@louisville.edu. 


\title{
A Study of the Acadente Sucoess of Veteran former probation Students in the \\ Coljege of Arts and Sczenoes of the University of Louzivilla
}

\author{
A Dissertation \\ Subrat ted to the Revity \\ of the ireduate Sohool of the University of Louisville \\ In Partial Fuidiluent of the \\ frequirements for the Dagree of \\ haster of Arts
}

Departmint of Education

by

Rollin E. Godfrey

Auguat 1947 


\begin{tabular}{|c|c|}
\hline \multirow[t]{3}{*}{ TITLE of THESI } & A Study of the Aondento sucoess of \\
\hline & Voteran Former Probation Students in the \\
\hline & college of 4 to and sel enoes of the \\
\hline
\end{tabular}

APPROVBD BY A READING CONITISE COMPOSED OF THE FOLLWTMG NOBBER:

DIRECOR Or THes I8: J. J. Oppenheimer

Guy Stevenson

DATE: 


\author{
A Study of the Acadento Success of \\ Veteran Former Probation Students in the \\ College of Arts and Soienoes of the \\ University of Louisvilie
}




\section{TABLE OF CONTENTS}

GHAPTER

III The Aoademic Progreas of the Veteran Former Probation Student

IV The Relationship of High School Rank and the Freshmen Tests to the Academic Progress of the Veteran Former Probation Student Encountered by Twelve Veteran Frobation Students. 


\section{LIST OF TABLES}

\section{TABLE}

I Rank in High School

II High School from wich Probation Students Oraduated

III Cholce of College lajor by High School Aank

IV. Choice of College lajor by High Schools

$\checkmark$ Difference Between Quality Points and Hours Before Probation or Dropped

VI Number of Terms in School Before Being fut on Probation or Dropped

VII Probation Student's Status, Harch, 1947

34

VII Number of Terms Needed for Probation Students to Regain a "G" Average

IX Probation Students' Age and Scholastic Standing March, 1947

X Rate of Change in College Wajor of Elghteen Frobation Students

XI Second Choloe of College Lajor and Scholastic Standing, March, 1947 


\section{LIST OF TABLES (Continued)}

XIII Scholastic Standing, Test Scores, and Vocational Choices of Frobation Students Ranking in the Middie Third in High School

XIV Seholastio Standing, Test Scores, and $V_{0-}$ cational Choices of Frobation Students Kanking in the Lower Third in High Sehool

XV Number of Students Haking Over Pifty, Between Twenty-Five and Pifty, and Under Twenty-Pire on the Psychologioal Test by High Sohool Rank and Soholastio Standing

XVI Number of Students Making Over Fifty, Between Twenty-Five and Fifty, and Under Trenty- Hive on the Feading Test by High School Rank and Soholastic Standing

XVII Frequency of Factors lientioned in Interviews as Alding or Retarding Academic Progress Both Before and After lilitary Service

XVIII Summary of Causes of Academic Diffleulty or Success Hentioned by Twelve Frobation Students in Interviews, with Total Academio Standing as of barch, 1947 
CHAFTER ONE

Introduction 
CHAPTER I

The University of Loul sville, like most other universities, played an important role in World Nar II in the training of Serrice lien for active duty in the Nayy, and now in the post-war era, finds herself taxed to the lindt to provlde educational faclitities for her many veteran students.

To admit large numbers of students, whether veteran or nonveteran, whout some sort of screening process to Identify thowe who obviously could not do college work would be wasteful of manpower and public moneys. The policy which the Univergity has used for many years $1 \mathrm{~s}$ known to be , valid procedure, and it is as fol10:8:

1. One must have graduated from a four-year accredited high school and have at least I5 acceptable units of credit.

2. In addition, every person wishing to enter as a freshman mist take the following tests, anong others:

General Scholastic Aptitude Test English Usage Teat

3. If one's arerage on these teats is in the lower quarter and he ranked in the lowest third in his high school class, he may be refused adniesion to the college.

When faced with huge post-wer enrollments, it was declded to continue this policy with the modification that veterans be given preferenoe over non-veterans whenever a question arose as to 1

Bulletin of the Univeraity of Louisvilie, College of Arts and Seienoes, VoI. Xi, Ho. 3, JuIy T946, p. I9 
which of the two groups be adwitted. The univergity felt obliged to provide first for those students who were currently enrolled in school, and next, for those wo were former students returning as veterans. Therefore, when selections were made, this group was provided for first. The majority of former students were veterans, eager to grasp new opportunities and to make up for past failures. Hany of them had left school with a poor record of soholastic achievement. When they returned from the Service, they were given the second highest priority for admission. The purpose of this study is to report on the progress of these veteran former students.

In order to understand more clearly the problem at hand, it seems wise to set forth the limitations of this study, and to establish a common bond of understanding by defining some of the terms and by describing some of the procedures which will be used in the analysis.

Prior to World War II, a number of male students regularly enrolled in the College of Liberal Arts, University of Louisville, were doing school work of inferior quality. As a result, they were placed on Academio Probation or were di missed from the College, depending upon the degree of inferiority of their scholorship. WIth the outbreak of the war, each of this grolp enlisted or was drafted into the Armed Forces. Jpon discharge from Service, each hastened to rementer college. Some have been in achool three or four terms since their discharge, while others hove been fil school only for one term. This study will attempt to shor whether or not these students are doing better scholastic work now than before 
before their perlod of military service.

For this investigation, there are available the academic records of seventy-five male students whose ages vary from twenty to thirty-two years. Three-fourths of this group gratuated from the three male high schools in the city of Iouisville, Kentuoky. They expressed interest in nine rocations or professions. The onefourth of the group who graduated from high schools other than in Loulsville represent five states. All but aix of the seventy-five students have been ranked as to their scholastic standing in their high school graduating class. Prlor to their first registration in the college, all but five of these students were given Freshmen Tests required of all new students. The latest acholastic standing that will be reported $w 111$ be for the spring harter, which anded in March, 1947.

This study will not attempt to show all the causes for poor scholarship. Hovever, it should be evident that, in some cases, a rapid decline in scholastio efficiency was due to the student's state of mind about entering the Armed Forces. In other instances, It will be obrlous that a change in a student's ajor or ocupational interest fected the desired improvement. To analy $y$ each indiVidual's scholastic problem is beyone the scope or intention of this report.

Thus far in this report, sereral terms have been used and several ideas projected whi ch ar not easily understood unless the reader is fantilar with the problems of most colleges and in particular, the University of Louisville. In the pages wich follow 
w1I be found terms wich w1I need clarification. Wost of these can be explained at this point.

When a high school student is about to graduate, his grades for the entire period in which ho ettended are averaged, and he is ranked scholastically in terms of the others who are to graduate with him. If he is a superior student, he will of co rse stand near the top of his class. In reporting his rank in high school to the college, his pincipal usually divides the entire class into thirds or fourths and indicates in which of the sections the student ranked. Nost of the high schools rejorting the rank of their students indicate that they were in either the upper, mlddle or lower third of their graduating class. This is a unt of measure which con be applied to every entering college student, and unless the graduating class is unusually small, it gives the college some idea of what the student has achieved while he was in high school.

It is required of all who enter the College that they take cetain examinations before they are admitted. The tests, administered by the Test Bureau of the College, are the American Council Psychological Examination, the Comoperative Linglish Test, and the co-operative General Culture Test. ${ }^{3}$ In order to be admisaable to the 0ollege, the prospective student must attain the twinty-fifth percentile in two of these three tests: The ACE Pgychological Total, American Council Pgychological Examinstion. Thurston and Thurston. The American Council on Education. 74/4 Jackson Rlare, Washington, D. C. 2

Cooperative English Bxamination. Davis and Others. Cooperative Test Service, 15 Ansteriam Ave. New York City.

3

Cooperative General Gulture Test. Chesire, Townsend, and Others. Cooperative Test Service, IS Amsterdam Ave. New York City. 
The Co-operative English Mechanics and The Co-operative English

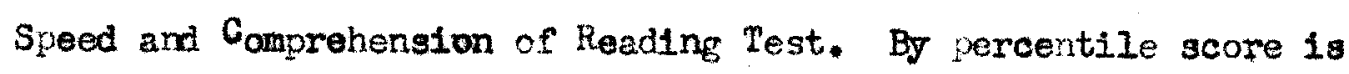
meant the percentage relat1onship of achievemen: of a student on a test as comrarod with other students either in his grous or in a large comparative grom. For 1nstince, if a student scores at the fourth fercentile on a test, only four vercent of the students In his grop marie a score lower than he $\mathrm{d}$, and ninety-six percent mide a higher scoro. If ho scored at the sixty-eighth percentile, sixty-ight percent of others scored below and thirtytwo percent above him. When a student seems to show sufficient maturity of purpose, even though he does not attain the twenty-fifth percentile on these tests, he nay be allowed to registor in the College with the recomendation that he take ferrer subjects until he has demonstrated thet he can do acce table work. It will be noted that a fer of the students in this study seer to fall in that category.

Progress in his college studies is reported to the student In terms of a letter grade. For this arpese, the College uses the letter "A" to report work of a supertor quality, "B" to indicate work better than average, "C" means average, "D" poor, "I" incomplete, and "F" failure. In order to obtain an average of the work done by a student in all his classes, it is necessary to assign numerical quivalents, usually called grade or quality points, for each of the letter grades. The basis for Indicating credit to be given a student for work completed is the semester or quarter hour. The numerical equivalent of the letter grade 
is besed on the same unit. For one hour of "A" work, the student receives three points; for a "B", two points; for a "C", one point; for a "D", O pointa; for an "F", a minus one point. To be in good scholastic standing, it is required that each student have as many points as he has total number of hours. This would be the same as a "C" average.

When a student falls behind as many as six points, he is put on Academic frobation and is prohibited from taking more than twelve or thirteen hours of college work, during the next term. If, during the next term, he does not do better work, he may be continued in probation. If, however, he contimues to do poor work and falls as many as thirteen points bohind the total number of hours he has earned, he will be dropped from the University for one term, and may not be re-admitted without aproval of a committee of the faculty, called the Bxecutive Committee.

The information to be found in the following chapters will be of value to the Faculty and Administrative Officers of the University of Louisville. Other colleges having a similar policy concerning academic probation may gain insight into the problems facing their own veteran former students. It is planned that this report may be the basis for further study regarding scholarship at this University. 
CHATER TWO

Survey of Related Iiterature 
CHAPTER II

Wach interest is being shown in all institutions of higher education in the scholastic performance of veterans. A quick look at the titles of articles concerning veteran scholarship as Iisted in recent issues of the Educational Index will give some Indication of the interest in this problem. Several studies report that the veteran is a good student. Some studies compare his scholestic success with that of the civilian atudent. However, very little information about the veteran student on aademic probation has been publlshed.

A study, completed in 1939 , by Heaton and Weedon, gives a comprehensive picture of the performance of probation students at four Michigan Colleges. The total group studied numbered 938 students. Ihis group was interviewed, tested, and were asked to contribute their ideas toward helplng to solve the problem of the "Fatling St dent". While this study does not take into account the student's rank in his high school graduating class, it does anaiyze, with great thoroughness, many of the social and economic factors affecting students living on college campuses. The more important finding regarding the psychologieal and reading tests are summartized as follow:

I

Educational Index, New York. The H. W. W1Ison Company, 19292

Heaton, K. L. and Weedon, V. The Failing Student. Chicago. The University of Chicago Fress. 1939. 279 pp.

3

Ibid. p. 50 
a) The scores on psychological examinations would indicate that mental ablifty such as is measured by such examinations is one imper tant factor, but not the only important factor, to be considered in the prediction of academic success and failure.

b) A broad range of a bility as measured by psychological tests is found among failing students, with many students with high scores included.

c) A broad range in degree of success is found among thcoe who receive low psychological scores at the of college entrance.

d) There is strong feeling among students, and same supporting data from the research, to support the feeling that the conditions under which examinations are given, and the mental attitude of students during enrollment week of the Freshman year, do not always permit an accusate measure of ability.

e) A considerable number of students with low reading a bility seem peovliarly handicapped on the American Council Psychological Examination because of the 1mportance of reading ability to success on the test. This suggests that an individual psychologic: 1 test might well be included in the Freshman test battery for use with students of lon reading ability.

f) A study of limited scope snggests that. the scores on the sroup psychological teat may be influenced by language handicaps, enotional instability, and physical deficiencies.

g) The percentage of high scores on paychological examinations among failing studenta is sufficient to call attention to diffioulties met by colleges in providing educational opportunities suited to the needs of students of superior intelligence.

In discussing the conclusions of their study, Heaton and 
Weedon have this to say:

The flndings of studies which involve human personality are usually complex. This is inescapable not because the investigators wish to have it so but because the factors involved in any individual's adjustment to a social situation are in themselves complex. The fact that human porsonality and its adjustments do not lend themselves to simple analysis will be understood by anyone who is a student of the basic sciences. They know that the total functioning peraonality can only be described in teins of a series of these basic scienges, each of which is in itself comilex. he biologist, as he explores his own field of biology, is moving farther away from simplicity to complexity. The same is true of those who study psychology, sociology, nutrition, health, and each of the other flelds of knowledge which are related to the life of the human organism. Then we recognize that the causes of academic fallure are multitudinou and combined in many comilicated patterns, we are merely verifying the discoveries nade in biology, psychology, and sociology, nu trition and health.

In thinking over the problens which aflect the academic

progress of the returned serviceman, one may be guided by a prewar study by Earle Idward Eme. This study of seventy-five Freshmen out of a class of one hundred thirty-seven, enrolled in a denominational college, reveals nineteen areas of difficulty and a total of 5,959 adjustment problems. I 3

Ibid. $p_{x} \cdot 246-7$

2

Eme. E. E. The Adjustment Problems of Breshmen.

Cokesbury Press. Nashville, Tern.

1938. $125 \mathrm{pp}$.

3

Ibid. p. 32 
AREA

TOTAL NO. OF

I. Courses

ADJUSTMENT EFOBLEMS

II. Religion

714

706

III. Teachers

468

IV. Economies

446

V. Library

VI. Educational Guidance and Control

443

VII. Personal Student Relations

393

VIII. Athletics

IX. Vocation

X. Rooming

XI. Voluntary, Social and Amusement Activities 261

XII. Other Colleges, Races, Cliques, etc. 257

XIII. Parental Relations

XIV. Health: Physicel and Mental

XV. Relations with Teachers outside of Class $15 \%$

XVI. Boarding

rVII. Special Ability

XVIII. Relation th Administrative Officers 53

XIX. Departmental, Pre-professional and Interest Oroups

Grand Total

5,959

The nineteen areas of experienoe are liated in order of h $\mathrm{v}$ ing the greatest number of adjustment problems. In conjunction with the interviews, three standardized tests were used, namely: The American Council Edication Test (1939), Thurstones lersonality Schedule, and Sim's Socio-Economic Status Test (Form C). The purpose of the tests was to measure intelligence, neurotic tendencies and socioeconomic status. From this stidy, it was noted that the intelligence factor did not ojerate in areas twelve through nineteen; $h$ igh neurotic tendencies were not operative in areas eleven through nineteen, and Iar socio-economic status did not affect areas eleven through nineteen.

In sumary, the study points out trat there are five areas of diffioulty in which two factors are operating with high significance, 
1. In the use of the library, low neurotio tendency and low socio-economic status were operating with high significance. But not so with Low irtelligence, for poor and highrate students reported about the same number of problens.

2. In the area of educational guidance and control, low inteli igence and low socio-economic status were functioning with high significance; and neurotic tendercy with some significance.

3. The economic area revealed the factors of intelligence and socio-econorice status functioning highly; and on neurotic tendency, low as well as high-rated stidents reportied a sinilar number of problems.

4. Again, in the area of relation with teacherg outside of class, intelligence and socioecon wio status were functioning very definiteIy; but neurotic tendency was not because low and high-rate students reported equal number of problems.

5. In the religion area, nevrotic tentency and socio-economic status were funotioning with high significnce; bit on intelligence the poor students reported only $2 \%$ more problems than did the brighter ones.

A doctoral dissertation preparod by Rajmond Loren Garnett at the University of Hissouri, in 1934, is one of the earlier studies of fectors in college success. This study is concerned with 1929 Freshman Class of the University of isssouri. The background of the 1929 Freahm Class was examined and characterized in terms of certain social and scholastic factors. the various social and scholastic factars were checked against freshnan success for the purpose of determining the extent to which each one alone differentisted between successful and unsuccessful students. The I

Garnett, F. L. Sone Factors in Collage Success. Unpublished Dorctor's Lissertation. Tniversity of 1hssouri. 1934. 65 p.. 
two factors which seemed to be basic and most valid for differentiating between successiul and unsuccessful freshmen were combined Into a University Aptitude Index. Ihis Index was in turn checked against freshman success to illustrate the techniques which would robably tend to bring to the University of Missouri more successful and fewer unsuccessful freshmen.

The extent to whioh the University Aptitude Index would differentiate between successful and unsuccessful freshen at the tine of entrance was not ascertained with any degree of finality because of the difficulty of determining a measure of freghman success and non-success. An arbitrary definition of fresiman success was used, the Aptitude Index technique was applied and illustrated, and its defects, possibilities and implications were pointed out.

The study attempted to answer the following questions concerning the 1929 freshman class of the university of lissouri:

1. Who goes to the University of Masouri? a. What is the social background of the freshnen?

b. What is the scholastic background of the freshnen

2. How well do the freshmen succeed in the University of 14ssouri?

3. Io that extent do certain single cocial and scholastic factors differentiate between successful and unsuccesaful freshmen and which of these factors are basic ones?

4. To what extent do the basic factors combined differentiate between successful and unsuccessful freshmen?

5. What guidance technigues wich w11 tend 
to bring to the University of Hissouri more successful and fewer unguccessful freshmen were implied in the study?

The Information upon which this study was based was derived from four sources:

1. The "Data Sheet for St dents in Fizher Educational Institutions", a form used by the lissouri State Educational Survey Commission in 1929, which was filled out by the freshmen themselves early in the school year;

2. The 1929 Edition of the Thur stone Psychological Examination for High School Graduates and College Freshmen;

3. The face of the Thurstone Fsychological Examination, upon which each student, at the time the examination was administered, wrote hto name, his sex, the name and location of the high school from which he grathated, the number of students in his high school greduating class, the date of his birth, his intended vocation, and the particular branch of that vocation;

4. The recards in the Offlce of the Registrar of the University of Mifsouri, wich inolude chiefly the student's admission certificate from high school and his permanent record of University scholarship.

This study included 876 subjects, or those of the 1929 Freshman 
Class who were given the Thurstone Psychological Examination. Approximately 150 freshmen did not report for the wamination, and consequentiy no data concerming them rere incliacied in the study.

Dr. Garnett Summarized:

1. The size of the high school graduating class was a factor in University success, but $n$ t a strikingly significant one. Although graduates from large classes tencied to succeed at a higher rate tian graduates in small classes, the difference in rate of success is not marked enough to warrant the placing of much importance upon mere si,e of graduating class as a guccess factor.

2. The number of adranced courses taken in high school was also a factor in University success, but not a highly signj.ficant one. While students who were successful had an average of 4.4 units in advanced courses, unsuccessful students had only 4.1 units in adranced courses. However, the difierence between success and non-success cannot be reduced to a difference in the number of advanced courses pursued in high school. Although this factor appars to have some significance in success it is not a basic factor.

3. Rank in the high school graduatine cluss is a highly significant factor in University success. While 7.2 per cent of those students who were in the higher third of their high school graduating classes were successful, only 31.5 per cent of those in the lowest third with suecess. A student ranking in the highest one-third of his class appears to have twice as good a chanoe as does a student in the lowest one-third. These facts appear sufficientiy significant to justify the selection of rank in the high school graduating class as a basic faotor in University success.

4. Thurstone Psychological Examination ability 
2180 ia a significant factor in Unitexsity success. When the Thurstoen Psychologlcal Examination scores of all. fr simen were arrangad on a percentile scale, 15.5 per cent of those in the lorest quintile, 26.8 per cent of those in the second quintile, 32.2 per cent of those in the third, 50 per cent of those in the fourth ait 79 per cent of those in the highest iuincile vere suocessful, of all the students in the lowest decile, 11.4 per cent were sucm cessful, and of all those in the higiest decile, 8.2 per cent were successful. Without doubt Ihurstone sychological txamination ability is a decidedily injortant facto. in jniversity success.

5. High sehol rank and Thurstone Psychological Wranination ability combine to form a more significant factor in University succese than any of the other factors considered in this study. When the index for 598 students for whom both the above mentioned measures were available were arranged eccorting to University Aptitude Indor scale, the percentage of successful students of all those in each 10-point step from the lowest to the highest rere found to be as follows: $0,6.5,11.5,21.4,32.6$, $37.5,59.3,71.8,06.5$ and 100 of a 11 the 86 students who feil below 30 on the aptitude scale, only eisht, or 9.3 per cent, were successful. of the 186 stidents who fell above the 69 point on the aptitude scale, 152 , or 91.7 per cent were sccessinl. of ali the successfil stidents only 2.8 per cent were found below the 30 point on the scale. In other words, 97.2 per cent of all successful students had an autitude index above 29. The unguccessful students are more 1ikely to be found on any point of the scale below $\%$ than are the successful ones. The chances for success af the studen s falling on the various ten steps of the aptitude scale from the lowest to the highest are: no chance at al1, 1 in $1 . .5,6.7,4.7,3.1,2.7,1.7$, 1.4, 1.2 , and 1.0 respectively on the lower half of the aptit de scale there 


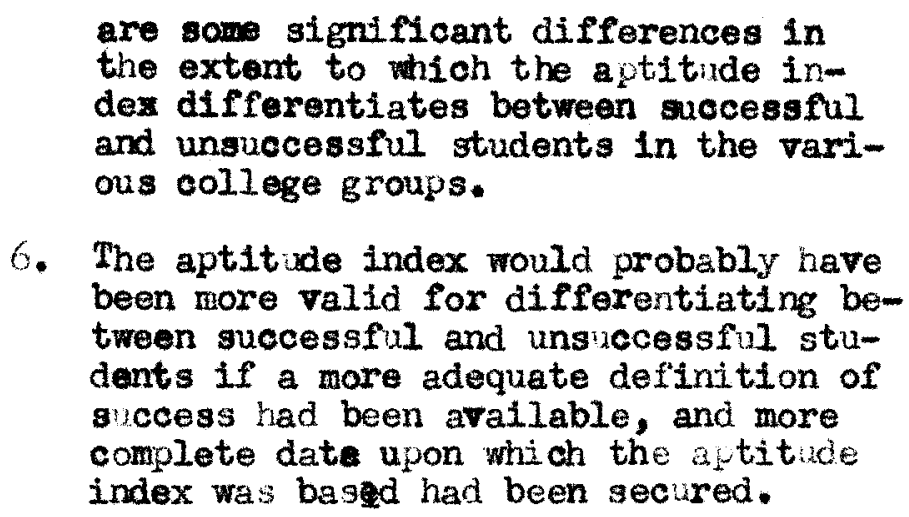

Wr. Exmest L. Welborn, Indiana State Teachers College, lierre Haute, Indiana, finds thet the average scholarship index of reterans in all subjects combined was only slightly higher than that of citilians, the superiority being about the same as that in centile scores made on the Amestcan Council Psyohological Exam2 ination. He further reports, in a comvarison of the pre-war and post-war scholarship of veterans, th t the difference in the two scholastic indexes covered a wide range and were negative in one-fifth of the cases. The mean change was equivalont to a little less than three-fifths of a letter grade. Horeover, the size of the gains was in inverse ratio to the size of the pre-war index; this is due to the greater relative ease of bettering poor marks than good ones. It was concluded that there was little relationship between gains on the one hend and AOE centile, age, marital status, college classifloation, and academic load on the other hand. In drawing conclusions from the study, Ur. Welborn ha this I

Welborn, E. I. "The Bchol rghip of Veterans Attending a Teachers College." Journal of Educational Research. 40:209-15

2 November, 1916

American Counc1l Psychological Examination. Thurston and Murston. The therican Councli on Education. 7ul Jackson Hace, Washington, $D, C$. 
To say about the scholarship of Veterans:

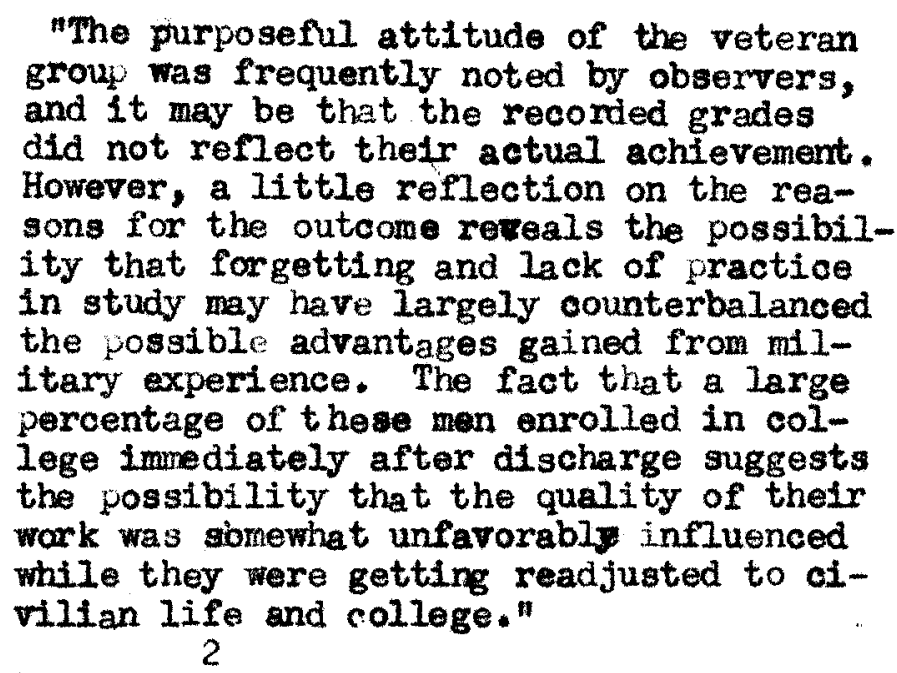

Darid F. Votaw, also witing in the Journal of Educationa Research may have solred some of the problems posed in "The Failing Student". He reported data on the predictive value of a battery of tests given to freshmen entering college. While this article is not concerned primarily with veterans nor with probation students, its findings should undoubtedly be of value to the University of Loui sville's College of Arts and Soience in predicting the academic future of its own one thousand presently enrolled freshmen. Hr. Votaw gave four hundred twelve entering freshmen at Southwest Texas State College, San Karcos, Texas, the American Council Psychological Examination, the Co-operative English Exam3 Ination, and the Use of Library and Study Materials Test. Scores on each Test were converted to $\mathrm{T}$ scores providing a uniform mean I 2

Votaw, D. F. "A Comparison of Test Scores of Entering College Freshmen as Instruments for Predicting Subsequent Scholarship."

3

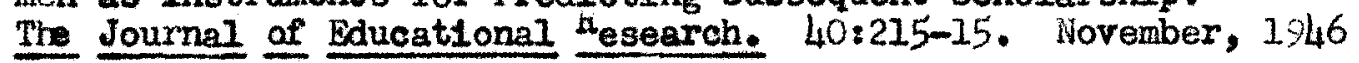

Co-operative English Examination. Davis and Others. Comoperative 4 Teat Service. 15 Amsterdam Ave. New York City.

Use of Library and Study Heterials Test. Kilpatrick and Others. The Steck company. Austin, Texas 
of fifty and a standard deviation of ten. At the end of the freshman year the grade-point average was computed for each student and from this data the correlation coefficients were computed. Ihis study concludes that in a combintion of the Fychological Bxamination scores, English seores nd Library Test scores to predict subsequent scholastic success of entring college freshren, the library score contributed the greatest weight. Furthinore, college freshmen whose high school period coincided with the war years were inferior in library skills. This may bave been caused by the curtaliment of Ilbrary service in the high schools, as a result of the teacher shortage.

In an article apparing in the April, 194?, issue of the Journal of the American Association of Collegiate Registrars, Mr. J. A. Humphreys summarized the problems facing most institutions as they attempt to meet the needs of their veteran students. To understand better the personal problems of the veterans, Mr. Humphreys suggests that:

1. Veterans are moxe ture in age and reneral out-look than are most of the non-veterans in the student body.

2. The veteran wants to make rapid progress toward his educational and vocational goal.

3. The voteran is under financial presanio and therefore experiences the emotional strains ordinarily associated with such pressure.

1 Humphreys, J.A. "Problems of Personal Service and the Veteran". Journal of the American Association of Oollege Registrars VoI. XXIT. Ho. 3. ApriI, 1947. p. 31I 
4. Some of the veterans, who did not graduate from high school and who entered on the basis of the tests of General Educational Development, feel keenly the added responsibility of making up for deficiencies which they should have received in regular high school classes.

5. Not too large a percent of the veterans now enrolled are definitely incapacitated emotionally and physically.

Although number 4 above cannot aply to any of the group included in this study, the other suggestions will identify themselves readily as the study of the academic progress of these seventy-five veteran probation students progresses in the following chapters. The college is in complete accard with Mr. Humphrey in the following statement:

$$
1
$$

"The sidilful handing of the veteran is the most challenging and most difflcult problem which $h$ s faced colleges and universities for some time."

I

Humphreys, J. A. op. cit. p. 316. 
CHAPTER THLEE

The Acadenic Progreas of the

Veteran Former Probation Student 
CHAPTER III

Bighteen percent of the seventy-five students included in this reper $t$ came from outside Louisville and Jefferson County, thereby indicating that the remaining eighty-two pereent were able to live at home and continue their education much the same as though they were yet in high school. Other factors being equal, It would seem that scholastic progress and adjustment to college Iife would not hare been a great problem to the latter group. In Table I 117 be found a record of achievement in high school for the entire group of seventy-five. Ordinarily, one would not axpect to find twenty-eight percent of a group of probation students to have graduated in the upper third of their high school class, and especially since most of them were not confronted with havIng to make the adjustments most students make upon leaving home for the first time. On the other hand, howrever, this group was awaiting the call to military service, and their anxiety about it mast not be overlooked.

The group of students graduating in the lower third is not a typical group. Except in rare cases, this group of lower third graduates was required to attain the twenty-fifth percentile on certain of their Freshman Testa in order to be admitted to the college. It is not likely that a typicel grou would be able to do this.

Because it seemed a more reliable index, percentage as well as freguency figures have been quoted in nearly all of the bables in this study. In noting that twenty-eight students out of the total 


\section{TABLE I}

RANK IN HIOH SOHOOL ORADUATINO CLASS OF SEVENTX-FIVE HALE STUDENTS ON ACAUEUIC PROFAIION IN THE COLLEGE OF ARTS AND SCIENCES, UNIVERSITY OF LOUISVILLE, BEFORE THEIR MILITARY SERVICE.

RANK

Upper Third

Hidle Third

Lower Thind

Not Stated
TOTAL

21

28

20

6

$75^{\prime}$
\% TOTAL

28,00

37.33

26.67

8.00

100.00 
of seventy-five were gradusted from high school in the middle third of their class, the relationship does not immediately become as apparent as when we note that twenty-eight is over thirty-seven percent of the total.

In Table II, the schools that are represented can be een along with the rank at graduation of students from each school. Nearly seventy-fj.ve percent of these students came from non com educational high schools. This really does not prove that graduates coming irrom co-educational high schools do better work, because there is no comparison of that figure with the total number af students not on probation coming from the se schools. One may ask why Male and Kanual High Schools are practioally alone in the group of schools whose lower thind puptls are able to gain admission to the College by reans of their Freshmen Tests and then show scholagtic deficiency after they enroll. There is no answer apparont, but it is to be remembered that all of the se students laced military consaription, and that the behavior of this group is frobably not like that of probation students under more nomal conditions. Before attempting to draw final conclusions from Table II, It would be well to look at Table III. This Table show the probation students' first choice of profession or occupation for which they set out to grepare while in college. It is avident that the majority of students entered the college hoping to prepare for Medicine or Dentistry. The fact that the University has a Medical School is undoubtedly responsible for the enthusiam for this profession. It is interesting, however, that in this particular group 
TABLE II

HIOH SCHOOLS FROM WHICH SEVWNTY-FIVE MALE FIOBATION STUDENS GRADUATWD, BY THEY RANK IN TUET ORADUATIIT CLASS.

\begin{tabular}{|c|c|c|c|c|c|}
\hline NABE OF SCHOOL & UrHER & MIDDLE & LOWER & NOT ETATEO & TOTAL \\
\hline Loul aville kale & $7(9.33 \%)$ & $20(13.33 \%)$ & $15(20.00 \%)$ & $2(2.678)$ & $34(45.338)$ \\
\hline Dupont Manual & $3(4.00 \%)$ & $5(6.67 \%)$ & $4(5.33 \%)$ & & $12(16.00 \%)$ \\
\hline St. Xavier & $4(5.33 \%)$ & $5(6.67 \%)$ & & $1(1.338)$ & $10(13.33 \%)$ \\
\hline Jefferson County & $2(2.67 \%)$ & $3(4.000)$ & & & $5(6.67 \%)$ \\
\hline Kentucky & $4(5.33 \%)$ & $3(4.00 \%)$ & & $1(1.33 \%)$ & $8(10.67 \%)$ \\
\hline Out of State & $1(1.33 \%)$ & $2(2.67 \%)$ & $1(1.33 \%)$ & $2(2.678)$ & $6(8.00 \%)$ \\
\hline
\end{tabular}


FROBATION STUOENT'S EIRST CHOICE $F$ MAJOR IN COLIEGK BY HIOH SCHOOL RANK HAJOR INTHREST UPERR MIDULE LOWER MOT STATED TOTAL Wedical and Dental $10(13.33 \%) \quad 12(16.00 \%) \quad 7(9.33 \%) \quad 3(4.00 \%) \quad 32(42.67 \%)$

$\begin{array}{llllll}\text { Law } & 4(5.33 \%) & 6(8.00 \%) & 5(6.67 \%) & 15(20.00 \%) \\ \begin{array}{l}\text { Accounting and } \\ \text { Economics }\end{array} & 4(5.33 \%) & 5(6.67 \%) & 4(5.33 \%) & 1(1.33 \%) & 14(18.67 \%) \\ \text { Chemistry } & 2(2.67 \%) & 1(1.33 \%) & 1(1.33 \%) & 1(1.33 \%) & 5(6.67 \%) \\ \text { Engineering } & & 2(2.67 \%) & 1(1.33 \%) & 3(4.00 \%) \\ \begin{array}{l}\text { History and } \\ \text { Political Science }\end{array} & 1(1.33 \%) & 1(1.33 \%) & 2(2.67 \%) \\ \begin{array}{l}\text { Physical Education } \\ \text { Sociology }\end{array} & 1(1.33 \%) & 1(1.33 \%) & 2(2.67 \%) \\ \text { Mathematics } & & 1(1.33 \%) & 1(1.33 \%) \\ \end{array}$


of seventy-five, the upper and middle third graduates chose liedicine or Dentistry and the lower third graduates chose 1aw, and that intereat in Economics and Accounting was more or less evenly divided among all three.

The interests of students coming fron the various high schools are shown to be mainly Ledicine, Law, and Accounting. The other six rocations, listed in Table IV, cotal about eighteen percent of the group. The ratio between ledicine, Law and Accounting varies from high school to high sohool; though not necessarily signiflcant to this study, it is interesting. Pre-medical probation students from Wale and Mamal High Schools double the number interested in prelaw or accounting. On the other hand, probation students coming from St. Xavier desire to take Accounting in preference to Law or hedicine, by the same ratio. Further evidence of the drawing power of the University Ledical School ts shown in the choice of study by those students coming from out of the state of Kentucky. Here again one should remember that this is the first choice of major or occupational interest as manifested by the probation students. Later in this study, the interests of some of this group are show to be slightly different since their return from the Service.

From these first four Tables, a rather definite plcture of the probation student should be forming. First, he has graduated from high school, seventy-five percent of this group from a Lous sville High School. The probation student is as likely to have graduatod in the upper third of his class as he is fron the lower. His interest 
TABLE IV

PROBATION STUDENTS FIRST CHOIOE OF BAJOK IN COLIAOE BY HICH SCHOOLS

MAJOF INTEREST

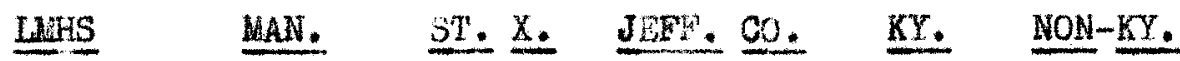

Ledicel and Dental $\quad 13(17.33 \%) \quad 5(6.67 \%) \quad 3(4.00 \%) \quad 3(4.00 \%) \quad 3(4.00 \%) \quad 5(6.67 \%)$

Law

$7(9.33 \%) \quad 3(4.00 \%) \quad 1(1.33 \%) \quad 1(1.33 \%) \quad 2(2.67 \%) \quad 1(1.33 \%)$

Accounting and

Econondes

$6(8.00 \%) \quad 2(2.67 \%) \quad 5(6.67 \%) \quad 1(1.33 \%)$

Chemistry

$4(5.33 \%) \quad I(1.33 \%)$

Engineering

$1(1.33 \%) \quad 1(1.33 \%)$

$1(1.33 \%)$

Heatary and

$1(1.33 \%)$

$1(1.33 \%)$

Polltical Sclence

$1\left(1.33^{*}\right)$

$1(1.33 \%)$

Physical Education

Sociology

$1\left(1.33^{m}\right)$

Mathematics

$1(1.33 \%)$ 
In attending the University was mainly to prepare fur Medicine, Law or Economies and Accounting other information which oould be of value in discovering traits of the probation group are the student's age, his perfarmance on the Freshmen Tests, and a report on the scholastic standing of arch. 1947.

In gathering information concerning the probation students, it was impossible not to discover the wide varlations in the administration of the probation system of the College. This messitates some explanation.

Academio robation is administered by a comittee of faculty members which meets at regular intervals to hoar the petitions of students desiring academic privilege, and which establishes the policies regarding probation for the College. In the interest of the College, these pollcles must always remain flexible. For example, the comnttee's pollcies regarding the retumed oervicemen $h_{g}$ ve been most lentent. It is obvious that students who face induction into the Service for combat duty are not likely to spend their last terms in college to bust adrantage. Upon their return, these students took advantage of the op portunity to petition the comnittee to have that last term's record eraed, if it rowld benefit them. Many of the students who took this opportunity were so far bohtnd in quality points that they are st111. on probation. For others, it was the means whereby.thoy could regain scholastic adeptance.

Table $\mathbf{Y}$ shows a wide diversity in probation polieles as applied to the several students of this study. As compared with the present policy of the Comittee outlined earlicr, fifty-two percent of the pro- 


\section{TABLE}

DIFFERENCE BETHEGN QUALITY FOTNTS AND HOURS BEFORE FROBATION STUDEATS WERE FIRST FUT OA PROBATIOW OR DROHED.

OVER 30

NUMBER OF STUDENTS

PERCENT OF STUDENTS

$25-30$

1

1.33

$20-25$

3

4.00

$15-20$

3

4.00

$10-15$

21

28.00

$5-10$

39

52.00

$0-5$

$\frac{8}{75}$

10.67

TOTALS

75

100.00 
bation group were subjected to the same treatment as their postwar brothers. Thirty-seven peroent received more scholastic 10niency, and ten percent received less than students presently enrolled in the college.

In preparing the data for Tables VI and VII, individual prom file charts were made. Each chart showed by terms the difference between the total hours credit and totai quality points eamed. When the two totals were the same, the student had a "c" average. A mid-point of "C" was drawn on the vertical axds of the chart. other points above and below it represented intervals of three quality points difference above or below a "on average. The number of terms the student stajed in school was indicated on the horizontal axis. By plotting the scholastic standing of the student each term and comecting the points thus plotted, a broken-1ine graph developed. Scholastic progress thus presented quickly showed fuctuation in the student's cutput. A veneral sumary of the probation student's stay in school before he was pat on probation or dropped, was made, and the results are to be soen in Table VI. Fifty-five percent of this group did not avoid probation beyond their first tern in College. By the end of the second term, wore than seventy-nine percent of the probation group were either on on probation or dropped. It cannot be assumed that this is a normal patterm for all students entering college, for these students were about to be drafted into lifitary service.

Since they have returmed, however, the scholastic progress of the probation students has been interesting to note. Table VII 


\section{TABLE VI}

PROBATION STUDENTS IRE-WAR STAY IN SCHOUL BHWORE THEY WERE PUT ON ACADEMIC PROBATION OR DROPPED.

$\begin{array}{ccc}\text { NO. TERPS } & \text { PERCENT STUDENTS } \\ 1 & 40 & 55.33 \\ 2 & 18 & 24.00 \\ 3 & 8 & 10.67 \\ 4 & 5 & 6.67 \\ 5 & 3 & 4.00 \\ 6 & 1 & 1.33\end{array}$


TABLE VII

FROBATION STUDENTS' DIFFERENCE BETWEEN TOTAL WUAITY POINTS AND TOTAL HOURS AS OF MARCH, 1947.

NO. QUALITY POINTS NO. STUDENTS PERCENT STUDENTS CUMULATIVE

19 and over

13

17.33

50.67

15-19

4

5.33

33.33

$10-14$

4

5.33

28.00

$5-9$

6

8.00

22.67

$1-4$

10

13.33

14.67

"C" Average

1

1.33

1.33

-1 to -4

3

4.00

4.00

-5 to -9

6

-10 to -14

3

8.00

12.00

-15 to -19

4

4.00

16.00

over 20

21

5.33

21.33

75

28,00

49.33

100.00 
show the number of quality points atove or below a "C" arerage that these probation students have been able to acquire. The Cumulative Percentage column runs in two directions. First, it includes those students who have brougbt their scholgstic standing up to a "c" average and second, it runs downward from a "c" to those students who have not been able to better their standing since their return. To summarize from the Camulative Fercentage colum, the probation studenta' performance since their return from Service, and as of Hareh, 1947, one would report that glightly over fifty percent of all the students who were on academic probation before leaving for militery service are now in good standing. At the ane time, however, twenty-eight porcent of the group has dropped bohind, and for them to regain a "o" average in time for graduation or transfer to a professional school is almost inpossible. About forty-nine percent of the group on probation before milftary service are still below a "C" arerage, and only about twenty-one percent can ever hope to extricate thenselves, because it is required that a student who graduates or who transfers to a professional school have at least a "C" average. On the basts of present policy, approadmately one third of these probation students are eligible for immediate diamisaal from the College by the Executive Committee. Those students who do manage to get of probation require more than one term in which to do 1t. Table VIII shows that eightyseven percent of the group who are now off probation made the necessary scholastic improvement in from one to three turns. The remaining thirteen percent required from four to ten terms. Further inves- 
TABLE VIII

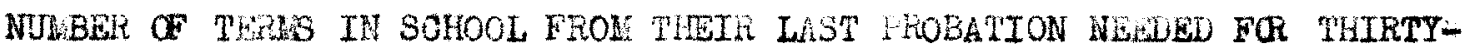
EIGHT WUBATION STUDENTS TO BHING UF THER SOHOLASTIC STANUINO TO A "C" AVERAGE.

NO. TERUS

1

2

3

4

5

6

7

8

9

10
NO. STUDEN TS

15

11

7

2

3

0

1

0

0

0 
tigation at a later date may alter the data somewhat, but the purpose of this study is to report the conditions as they existed at the end of the Spring Quarter, 1947.

In the group of students included in this study are to be found those who are barely twenty and those who are over thirty years of age. Each has come under the influence of military training and experience, but not necessarily under combat conditions. From the number who have extricated themselves from academic probation, it is assumed that these students become more adult in their ideas about the purpose of eduation. Table IX shows a distribution acoording to age of the entire group of probation students. Twentyfour percent of the probation group, aged twenty-three or under, and equalling twenty-one percent of the entire total, are still on probation. The group aged trenty-six and over represent about seventeen percent of the total group. Five percent of the total number who are over twenty-six and are gtill on probation, and twelve percent off.

The group aged twenty-three to twenty-five embraces fifty-seven percent of the total. Twenty-eight percent are on probation and twenty-nine percent are off. From information given above, it seems likely that greater age has brought greater responsibility and along with it, a greater determination to succeed in college.

uny atudents who indicated an interest in certain vocational and professional interests before they left for kilitary Service have, for various reasons, dscided that they arere perhaps preparing for the wrong oocupation. The change, notable in Table $x$, is overwhelmingly from Medicine to Economios. Ihis may be due to the fact that the 


\section{TABLE IX}

DISTRIBUTION OF PROBATION STUDENTS ACCORDING 90 AGE, DECEMBEH 146 , AND SCHOLASTIC STANDING AS OP MAECH, 147.

$\begin{array}{lccc}\text { AOE } & \begin{array}{c}\text { NO AND FERCENT } \\ \text { TOTAL }\end{array} & \text { NO. AND PERCENT ON } & \text { NO. AND PERCENT OFF } \\ 32 & 1(1.33 \%) & 1(1.33 \%) \\ 31 & 1(1.33 \%) & 1(1.33 \%) \\ 30 & 0 & & \\ 29 & 0 & 1(1.33 \%) & \\ 28 & 2(2.67 \%) & 0 & 1(1.33 \%) \\ 27 & 1(1.33 \%) & 3(4.00 \%) & 1(1.33 \%) \\ 26 & 8(10.76 \%) & 6(8.00 \%) & 5(6.67 \%) \\ 25 & 14(18.67 \%) & 8(10.67 \%) & 8(10.67 \%) \\ 24 & 12(16.00 \%) & 7(9.33 \%) & 4(5.33 \%) \\ 23 & 17(22.67 \%) & 5(6.67 \%) & 10(13.33 \%) \\ 22 & 9(12.00 \%) & 4(5.33 \%) & 4(5.33 \%) \\ 21 & 7(9.33 \%) & 0 & 3(4.00 \%) \\ 20 & 2(2.67 \%) & 1(1.33 \%) & 2(2.67 \%) \\ \text { Unknomn } & & & \end{array}$




\section{TABLE $\mathrm{X}$}

RATE OF GHANGE IN ZAJCR OF 18 RROBATION STUDENTS AS OF MAICH, 1947

MAJOR INTEFEST

Hedicine to Economies

Bngineering to Economios

Mathomatics to Economies

Chemistry to Economios

Law to Psychology

Medicine to Psychology

Engineering to English

Hedioine to Physics

Law to Bducation

Selence to Soctology

Physical Education to Law
NURBER

7

1

1

1

2

1

1

1

1

1

1

18
PERCENT OF ORIGINAL Grot?

9.33

1.33

1.33

1.33

2.67

1.33

1.33

1.33

1.33

1.33

1.83

24. 00 
the College is now offering a Bachelar of Seience in Commerce degree, In which there is no foreign language requirement. It is more likely, however, that to prepere for Medicine would take more time than the student feels he has to spend in preparing himself to support his family, and he mut of necessity shorten his stay in college considerably. The maturing influenoe of military life has made the rom bation student im atient for accomplishments of his owm. If the student's mojor Interests as shown in Table XI are compared with those outined in Table III, the resultin difference is Interesting and worth of note. When these probation students began their college careers, over forty-two percent of them elected the course of pre-liedical training (See Table III). Since they have

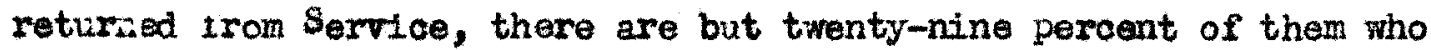
desire to complete such a course. On the other hand, before the war, about ninteen of this group chose Ecohomics and Accounting courses; as of Warch, 1947, thirty-one percent of the group desired that training. Notable also is the fact that interest in wajors such as $r$ sychology and Education has sprung up, and that, in one case, the 1uterest manifested in Hathematics is now directed to Economios. (See Table $x$ ).

In the nex; chapter, an attempt will be made to discover any relationship between the information thus far discussed and the scores made by these serenty-fire probation students on the Freshmen Tests. As a group, these reterans pose some interesting problems. If there Is any way in which their scholastic progress could be predicted on the bagis of information now available, much could be done to develop tham into nore effective citizens. 
SCHOLASTIC STANDINO OF PROBATION STUDENTS AS OF 1HROH, 1947, IN TERUS OF THEIR SECOND CHOIOE OF MAJOR OCCUFATIONAL INTTREST.

YAJOR INTEREST

Kedicine and Dental

Law

Economics and decounting $12(16.00 \%)$

Engineering

Seience

iilstory and

Polftical Seience

\$octology

Phyerioal Education

Psychology

Mnglish

Education
10. AND $\frac{\text { ERCENT ON }}{\text { PROBATION }}$

$11(14.67 \%)$

$6(8.00 \%)$

$2(2.67 \%)$

$1\left(1.33^{\circ}\right)$

0

$2(2.67 \%)$

0

0

0

0
NO. AND FERCENT OFT FROBATION

$11(14.67 \%)$

$7(9.33 \%)$

$21(14.67 \%)$

0

$2(2.67 \%)$

$2(2.67 \%)$

$1(1.33 \%)$

1( 1.33$)$

$4(14.67 \%)$

0

$1(1.33 \%)$ 


\section{CHAPTER FOUR}

The Relationship of High School Rank

and the Freshmen Tests to the Acadenic Progress

of the Veteran Former Probation Student 
CHATTER IV

At present, we have no way to measure a student's determination to succeed scholastically. Wunerous tests attempt to measure the likelihood of success in school, but there is no absolutely foolproof method. The admissions policy of the College is undoubtedly besed on this premise. In the Tables which follow are data which may substantiate this point of view. The data available on each of the students, as stated earlier, include his rank in high sohool, his age, his scores on the entrance tests, his major or occupational interest, and his scholastic record. His chance of getting off or remaining on probation are little affected by his age. It is possible that an examination of test scores will give a better picture of these students.

In Table I, it was shown that there were twenty-one probation students who graduated in the upper third of thetr high school graduating class. For reasons unknown, two of that number escaped takIng the Freshmen Tests. The data presented in Table XII is, therefore, based upon the scores of but nineteen, or twenty-five percent, of the total group. In comparing the rocational choses in the "on Probation" column and the "Orf Probation" column, it soems that a change of rocational plans has not enabled maxy upper third students to lift themselves from Probation. Four students changed their programs of study, three of which are still on probation. It is possible that the three were in their first term bock fron the Sertice 
SCHOLASTIC STANDIM AS OF MARCH, 1947, FSYCHOLOCICAL TOTAL AND RIADIMG SCORES, AND VOCATIONAL CHOICES, INCLDIIG CHANCES OF CHOICES, OF NINETEEN PROBATION STUDENTS WHO GRADUATED IN THE UPPER THIRD OF THEIR HIGH SCHOOL GRAOUATING CLASSES.

$$
\text { A-ON PROBATION }
$$

INDIVIDUAL : PERCENTIE SCORE ERRENTILE SCOEE FOR PSYC. TOTAL FOR FOG. TOTAL

VOCATIONAL CHOTCES

$\begin{array}{llll}\text { A } & 76 & 42 & \text { Econ. } \\ \text { B } & 68 & 80 & \text { Econ. } \\ \text { C } & 44 & 24 & \text { Med. } \\ \text { B } & 43 & 12 & \text { Wed.-Econ. } \\ \text { E } & 40 & - & \text { Sci.-Soc. } \\ \text { F } & 28 & 30 & \text { Med.-Econ. } \\ \text { a } & 22 & 38 & \text { Law } \\ \text { H } & 08 & - & \text { Med. } \\ \text { I } & 02 & - & \text { Mied. }\end{array}$

B-OFF EROBATION

INDIVIDUAL FEROEIITLE SOORE
FOR FSYC. TOTAL

PERCENTILE SCORE FOR RWD. TOTAL

$\begin{array}{lll}\text { J } & 87 & 60 \\ \mathrm{~K} & 81 & 76 \\ \mathrm{~L} & 69 & 99 \\ \mathrm{~N} & 68 & 95 \\ \mathrm{~N} & 49 & 78 \\ \mathrm{P} & 46 & - \\ \mathrm{P} & 43 & 12 \\ \mathrm{Q} & 40 & - \\ \mathrm{R} & 39 & 02 \\ \mathrm{~S} & 21 & 53\end{array}$

VOCATIONAL CHOTCES

Econ.

Law

Dent.

hed. - Psy.

Med.

Excon.

Ghem.

lued.

Iaw 
and that they needed more time to regain a "C" average. (See Table VIII)

Of the nine who remain on probation, two exceeded the fiftieth percentile on the Psychological Pest. Of those who are off probation, four exceeded this critical percent. On the Heading Test, one who is on and six who a re off probation made scores of fifty or above. Of those still on probation, three persons made scores of less than twenty-five on the pychological Test. of those who re off probation, only one individual is below the low centile. On the rieading Test, two persons in each group were below the twenty-fifth percentile. Generally speaking, then, the upper third graduate who made fifty or over on either of the two tests, is more likely to get off probation than the upper thind graduates who made less than flfty. Furthermore, it seems thet in this instance reading scores carry more welght in predicting scholarship than do the paychological scores.

In Table XIII, the data are based on the scores made by twentysix of the probation group who graduated in the middle third of their high school graduation class. Reference to Table I shows that the Freshmen Test scores of two students were not available. It is possible that several middle third students may have removed themselves from probation because they changed their vocational plans. Six changes of vocational choice are show, of which four are now noff Probation"

of the middle thind group making rifty or over on the psychological Test, one is on probation and six are off. of the group making fifty or over on the Reading Test, two are on and three are off 
WARCH, 1947, SCHOLASTIC STAWDIN, FSYCHOLOGICAL TOTAL AND R AUING SCOIES, AND VOCATIOAL CKOICES, INCL DINO GHANGES OF CHOICES, OF THENTY-SIX HOBATION STUDENTS WHO GRADUATED IN THE HIDLLE THIRO OF THEIN HICH SCHOOL GRADUATING CTASS.

INDIVIDUAL PERCBMILP SCORES PROBATION ON FSY. TOTAL ON BWG. TOTAL
A 62
47
46
33
32
24
$1 \%$
16
14
of
04
02

49

46

38

49

50

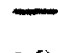

18

02

06

12

on

o
VOCATIORAL CHOTCES

Hed.

Iaw

Dent.

Thys. Ed .-Law

Econ.

Ned.

Econ.

Nied.

Singr.

Rng.-ilcon.

Med.

l.

B-OFE REOBATIOS

INOIVIDUAL BERCWNTLE SCOTE TLRCETTILE SCONA

M

N

0

P

Q

R

3

T

U

V

W

$\mathrm{X}$

$\mathbf{Y}$

Z

\section{OH $3^{\circ}$. TOML}

91

72

68

63

58

57

44

42

40

30

25

24

19

15
ON HG. TOTAL

94

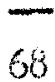

87

31

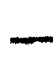

20

78

20

12

02

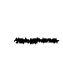

17

05
VOCATTONAL CHOICES

rsy.

Iaw

Econ.

Chem.

hed.-Econ.

Ixav

Med.

Pol. Sci.

Law.-3sy.

Hed.-Scon.

Med.

werd.

Econ.

Med. 
probation. Of those who made twenty-five or less on the Prychological Test, seven are on and three are off probation. Those twenty-five and below on the Reading Test total six on probation and six off probation. For this group, then, it seems that high scores on the Psychological Test are more important factors in success than Reading Scores.

The group of probation students who graduated from high school in the lower third of their graduating class is especially interestIng. These students were admitted as borclerline cases, and it was doubtful that they could perform college work of any great benefit. to themselves. Table XIV shows their test scores and rocational choices. Ten out of ninetein of these students have been able to achieve scholastic success since returning from Service. Six of this group changed their rocational objectives, and three of them are off probation. Six of the nineteen made fifty or over on the Fsychological Test, four of whioh are off probation. Bive made fifty or over on the Reacing Test, and three are off probation. Eight students made twenty-five or less on the Reading Test; three are off probation. Accordingly, the lower third probation students seem to be doing reasonably 1 in school since their return from service. The remainder of the chapter will be devoted to attempting to relate the soholastic performance of upper, middle and lower third groups to their test scores.

In attempting to discover relationship between high school rank, test scores, and scholastic standing in laroh, 1947, several 
MARCH, 1947, SCHOLASTIC STANDINO, ESTCHOLOGICAL TOTAL AND READING SCORES AN VOCATIONAL CHOICES, THCLUDINO CHANGES $\sigma$ CHOICES, OF NINETEEN PROBATION STUDENT WHO ORADUATED IN THE LOWER THLRD OF TEIR HIOH SCHOOL CLASS.

$\$ O N$ MOBATION

INDIVIDUAL TROENTILE SCOFES ON $\mathrm{BS}^{\top}$. TOTAL

A

B

$\mathrm{C}$

$\mathrm{D}$

E

r

a

H

$I$

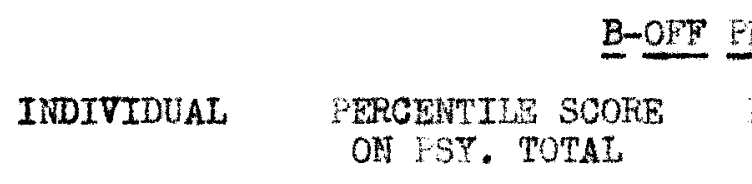

$\mathrm{J}$

K

L.

H

N

0

$p$

$Q$

R

S
77

62

49

41

21

16

09

07

Do
PERCEHTILE SCORLS ON EDG. TOTAL

VOCATIONL CHOICFO

$\begin{array}{ll}59 & \text { Med.-Econ. } \\ 03 & \text { Dent. } \\ 12 & \text { Engr.-Eng. } \\ 46 & \text { Wed. } \\ 20 & \text { Dent. } \\ 46 & \text { Lath.-Econ. } \\ 80 & \text { Law } \\ 27 & \text { Lcon. } \\ 12 & \text { Law }\end{array}$

VOCATIONAL CHOICES PEROENTTE SCOHE
ON ROG. TOTAL

42

49

43

32

15

11

10
70

75

72

0

49

2

5
60

72

74

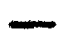

12

19

31

03

34
Chem.-Ben.

Hot stitad

Econ.

Iaw

Reon.

Soc.

Econ.

Hed. - Sci.

hed.

Mod. Phyre. Ed. 
correlations were made, using the pearson coeffieient of contingency. The cuefficient for the group still on probation March, 1947, between high school rank and heading scores is .200. Ihis indicates practically no relationshi at all. For the grop on probotion larch, 1947, the coefficient between high school rank and Psychological Total scores is .27?, only a slight bit higher. Both of these coefflcients show but little correlation between rank in high s chool and Psychological $\boldsymbol{\alpha}$ Reading Scores for the group on probation,

A relatively higher degree of correlation is show by the group of students whe are off probation by March, 1947. Between Reading scores and high school rank, it is .567 . This seerns to imply that factors other than ability, or lack of ability, to do college work have interfered and are interfering with the student now on probation.

In summary, a change of vocatlonal choice or major has benefitted seven out of the group of eighteen who attempted the change. Fifty percent of the lower third students on probation before entering military service are still on probation. For the se in the upper and middle thirds, the number remaining on probtion is forty-five, and forty-aight percent, respectively. Oood scores on the psychological and Reading tests seem to combine to hel the higher ranking student pli away from probation, once he is on it, but only the Paychologloal Scores seem reliable in predicting the scholastio future of a lerer thind graduate who is put on Probation.

Tables XV and XVI tend to summarine the relationship, if any, between test soores, high school rank, and scholastic standing of those veterans tho were on Academic robation before their texm 


\section{TABLET XV}

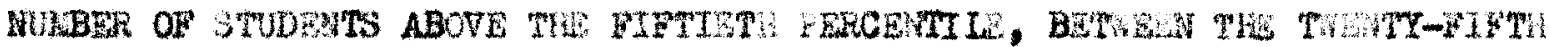

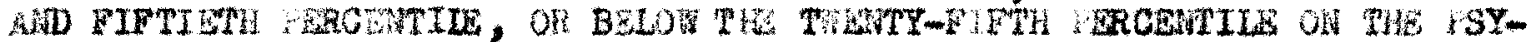

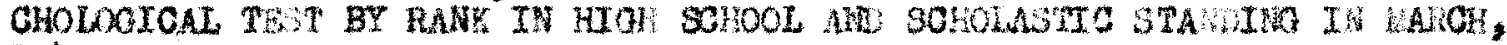
1947.

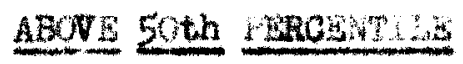

BAKK IN HOH SCHOOL.

Undert

MLIULE

Low ins
On robation

2

1

$\frac{2}{5}$
OW HOBAFIOW

4

6

4

$\boldsymbol{u}_{3}$

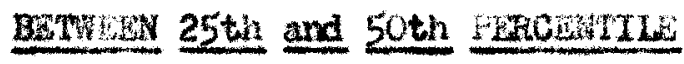

RAKK IN HIOH SOHOOL

$$
\begin{aligned}
& \text { Up } \\
& \text { WTDOLE }
\end{aligned}
$$

What
ON SORBATLOH

4

h.

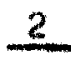

10
OFE WOBATIOK

5

5

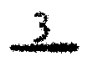

23

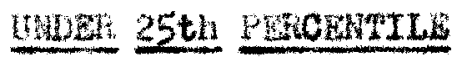

MWK IH LICH SCHoOL

WHat

WrowL

Whing
ON HOLATOH

3

7

5

13
OHF LOBAII GA

1

3

3

7 


\section{TABLE XVI}

NUBBER OF STDEENS ABOVE THE FIFTIETH PERCENTISE, BETWEN THE TWETT-FIFTH AND FIFTIETH PERCENTILE, OR BELOW THE TWENTY-FIFTI FRCENTILE ON THE READING TEST BY RANK IN HIGH SCHOOL AND SCHOLASTIC STANDTN, WLACK, 1947.

ABOVE SOth PERCEUTILE

RANK IN HICH SCHOOL

JPFER

UTDDLE

LOWER
ON WROBATION

1

2

$\frac{2}{5}$

BETHEIN 25th and 50th PERCENTLLE

RANK IN HIGH SCHOOL

UFEER

MIDULE

LOWPE

Dincin 25th and 5oth Parcan

ON PROBATJON
OFF PROBATION

6

3

3

12

OFF FLOBATI ON
6
4
3

13
2

5

4

11

UNDER 25th FERCENTILE

RANK IN HIGH SCHOOL

UPHER

NIDDLE

LOWER
ON PROBATION

2

6

4

12
OFF ROBATION

2

6

3

11 
of military service. If a student ranked in th upoer or middle thitrd of high school and made over fifty on the fsychological Test, his chances of getting of propation are ten out of thirteen, and much greater than those of the student who made twenty-five or less on the test, whose chances are four out of fourteen. The same may be said of the Reading scores, where the chances are nine out of twelve for students making over fifty as compared with eight out of sixteen for students making under twenty-five. The "lower third" student's chances are four out of six, if he made over fifty on the fsychological Tests, three out of five on the Reading Test, and three out of eight if he made under twenty-five on the foychological Tests, three out $\alpha$ seven on the Reading Test. This mold seen to indicate that test scores and high school rank a re important determinants in predicting a student's chances of getting off Academic Probation, onee he is on it.

In the next chapter, certain other factors which nay be operating to impede the progress of the group of upper and middle third students will be considered. Those students graduating in the uper and middle thirds and on probation, and those students graduating in the lower third and of probetion will be observed with the idee in mind of discovering ways in which the two group are similar and dissimilar. 


\section{CHA TUL NIVE}

Fro-Wer ad Postmar Scholagtic Hiflieulties

Incounterod by Treive Veteran Probation Students 


\section{GHARTW: $V$}

Seventy-1ive students were inal ded in this swoy. of that number, thixty-geven romined below " $\mathrm{C}$ " average at the end of the Spring warter, Warch, 1947. In an atterat to discover faotors which wht be operating to keop these students from attaining scholatic suecess, or frotors which might be conductive to success, twelve students ware interviewed. Of these twolve, waxere upper third high gchool graduates who have not been ablo to achleve a "g" ararage alnoe returning from Service. They are from the group of nine upper thinis remaining on probation after March, 1947. Ihroe are midrile third high sohool graduates atill on probation. They are from the group of twelve midile thirds atill on probation. The last group of three are Lower third high shool graduates who were

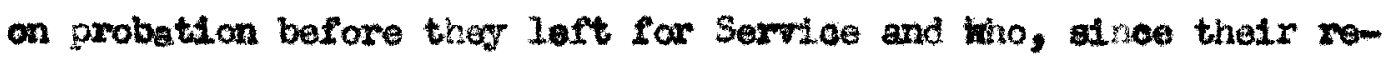
turn, hive achieved a total "d" average, or better. Soven others fall In this grou of sucoessful lower thinds. It was desired that 211 probation students oome for intervie but several found it im posalble to do so. Howerer, it is felt that the group inoluded here give ralipble gloture of the probation group as well as the anocessful groups. A11 but two students interviewed was giv $n$ the Bell Adjustment Imventory, with the 1dea in wind of sorrelating information gathered in interviews wh an objective instmunent. The results of the tosts are atated at the cles of each case study. Near the and $I$

"The Adfustment Inventary" hugh 1: Be11. Stenford Universit Press, Stantard Untrarsty, Galifornila. 
of the chapter will be found a summary of the findings of the se interviews which may be helpful to the College in its future policy toward veterans on probation.

I. UPEER THIRD HIOH SCHOOL GRADUATES ON FROBATION Individual "A"

"A", an upper third graduate of hale High School, was born warch 17, 1924. His father and mother are living, and he ta s a younger sister. Neither parent attended high school, but they seem to have provided for their chtldren very well. The father owns and operates a cafe, and the family lives in a seven room house. Apparently, they have all the comforts and conveniences onv would expect to find in the average American home.

"A" graduated from high $s$ chool with a grade of $64.6 \%$, and stood seventy-fourth in a class of 272. According to the otis Intelligence Test, Form A, ha I. 4. is 105 . On the entrance examination, he achieved the eighty-second percentile in History and the sixty-fifth in Science. His lowest scores were fourteen on both Scientifio Aptitude and English Mechanics. All his other scores range between twenty-five and fifty.

Upen entering college, "A" desired to become a chenist or chemical engineer, but during the three years he served as fight Engineer on a B-2L, he decided to change his major to Economics. In the one semester he attempted before leaving for the Service, 
he earned a total of fourteen and one half hours and nine and one half points, making $B$ in typing, C's in English and Yhysical Education, and $D^{\prime} \mathrm{s}$ in Algebra and Chemistry. In the four terms he has been in school since his return from Service, "A" has mo de $B^{\prime} s$ in Inglish Literature and Composition and Astronomy, C's in Economics, and D's in his other subjects. He hasn't failed in any course, but lacks the punch needed to maintain a "C" average. He was forced to withdraw from school during the winter warter for health reasons. He received surglcal treatment, but not successfully. Consequently, he is under the strain of worry about the fact that his condition is growing worse and does not respond to treatment. The following results are reper ted from the Bell Adjustment Inventory, Student Form, administered on May 29, 1947.

$$
\begin{array}{ll}
\text { Home Life } & - \text { Wood } \\
\text { Health } & - \text { Cood } \\
\text { Socially } & - \text { Very Aggresgive } \\
\text { Bnotionally } & - \text { Cood } \\
\text { Total Adjustment } & - \text { Excellent }
\end{array}
$$

If he can get his physical problem settled, "A" will probably be able to regain a "C" average before time for graduation. It is believed that only then cun he be expected to meet with much academic success.

\section{IWDTVIDUAL "B̈"}

"B" graduated upper third in the February, 1940, class at Vale High School. He was born May 24, 1921, and, until his marrigge in March, 1947, lived with his parents.

Prior to his admission to college, "B" took the Placement 
Tests. He attained above the fiftieth percentile in rsychological Ifinguistic Aptitude, Psychological Total, Effectiveness of Expression, theading, Current Soclological roblems and History. His lowest soores were English liechanics, .03, Fine Arts, 18, and liathematics, 18. ${ }^{4} 11$ other scores were between thirty-five and fifty. When he tock the Sophomore Comprehensive Fxamination in Nay, 1042, he rade about eighty on both History and Social Science and .07 in humanities.

"B" attended the college fo four terms before entering the Service, and pledged a fraternity as soon as it possible for him to do so. Since he decided a year or so earlier that he wanted business training, he elected a course along these lines, ilis highest grades, during the first year, were B's in Economics, He fatled English Composition his first semester, and agin in the second. In the second term, he also failed folitical Science. The first year ended th his having earned twenty-one hours and eleven and one half points. He was placed on probation by the Executive Committee. As a first semester sophomore, he earned fifteen hours and nine points, with $D^{\prime} s$ in Political seience and Humanities. In the second semester, he failed Humanities and made two C's and two D's. At the time of has induction, "B" had earned forty-eight hours and twenty-three and one half points. In looking back over this recond, "B" attributes his difficulties to the fact that he spent too much time th his Praternity and then, just prior to induction, became worried about the war situation. "B" served overseas with the Thind Army as a member of a "suicide squadron", so-called because of its high casualty rate. 
In the Service three years, he spent four months as a risoner of War. His three quarters in schoo], since his return, have been somewhat better. In this tine he has earned twelve hours $B$, twolve hours $C$, six hours $D$ and seven hours $F$ credit. "B" was dropped from school at the end of the Fall Guarter and, while out of school, he got married. He was re-admitted for the Spring luarter and now feels that he is doing moh better.

On the Bell Adjustment Inventory, he made the following scores:

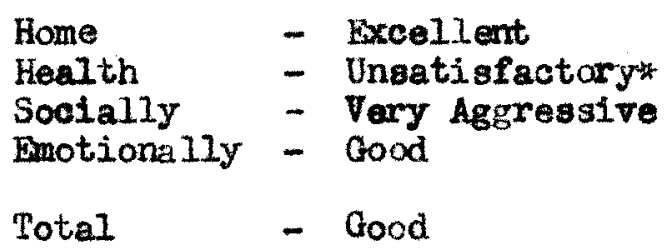

*This is further bourne out by reports of repeated absences from classes, followed by Doctor's statements showing treatment for colds, bronchitis, etc.

\section{INDIVIDUAL "C"}

"C", born August, 1921, ranked in the uper thind of his graduating class at Hamual Migh School, in June, 1940. He did not enter the University until September, 1941, during which time he probably worked his father and older brother in the drug store wich they om. "C's" gcores on the lacement Tests range from the sixtietin percentile on Current Sociat Problems to .07 in Effectiveness of Expression. Scores in English lectuanics, English Total, Soienoe, and hathematics are below the twenty-fifth percentile. All of his other test scores range between twenty-five and iffy.

"C" attended the college for nearly one Bemester before he 
left for the Service. He withdrew from school, thinking he had taken care of the offlcial part of leaving only to find, upon returning from three and a half years of Service as an $w_{\text {. }}$. that le had recelved F's in all his subjects but one and had been dismissed by the Exeoutive Comittee. His reocrd read, one-half hour credit, and eleven and one-half gality points. Unaware that he could petition the F's changes to W's, ho entered College in the Fall of 1946 on probation. During that quarter, re esned twelve hours and fifteen points, but of necessity remained on probation. After the Winter Quarter, he had earned a total of twenty-four hours and thixty points. It not until he was interviewed on Hay 29 that he learned he could be forgiven the work done imrediately prior to his entering the Service. Since his scholastic record was without fault when he comnenced, "C" did not take the Bel1 Adjustment Inventory.

"c'" major interest has been Law, but now that he is in business wi his fother, he feels that a major in Economics will meet his needs better. He says that his experience as a member of a Llitary Police Batallion influenced his change of major interest. Now that the Exeoutive Comittee has granted his petition, he is no longer eligible to be considered an "unsuccessful upper third probation student". This case is aignificant because it is typical of the numerous details wich operate when a study of college success is attempted. 


\section{INDIVIDUAL "D"}

"D", a graduate of Male High School in the upper third of his class, entered the University of Louisville in September, 1940. Two years of bookeeping and accounting in high school gave him some background for his decision to take up Business Administration when he entered college. Accordingly, his first semester subjects included English Composition, Introduction to Business, Political Sclence, Natural Science, French, Fhysical Education and Freshman orientation. When the grades were turned in, "D" had a D in FolItical Science, nd an $F$ in French. His other grades were C's. He was put on probation by the ixecutive Comeittee. The second semegter's program substituted Principles of Oeography for French, and at grade-time, only the D in Political Science kept him from a straight $C$ repa t. His probation continued.

As a Sophomore, "D" registered for Principles of Economics, Accounting, Introduction to Isterature, and History of Civilization. Grades earned for these courses were A, B, C and D respectively. He was removed from pobation, even though he was still four points below a "C" arerage. The fourth and last semester before he left for Service, "D" added four more hours of Inglish and Sociology to his schedule. When the grades were in, he had failed Frinoiples of Economics, made $D^{\prime} s$ in Accounting and History, a B in English and C's in all the others. He had a total academic standing of fifty-seven hours and forty-four points. He was returned to probation, but left sohool to enter the Service. Before going overseas, "D" was sent to the University of North Dakota for a basic 
engineering course in the A.S.T.P. In a program consiting of sciences courses chiefly, "D' made seven B's, seven C's and four D's - a total of forty hours and lorty-elght points. Overseas he was a machine gunner with the Infantry.

After discharge from the Army, "D" came back to Louisville, was married in August, 1946, and re-entered school. His grades have been C's or B's for the at two quarters, with a total standing of one hundred sixty-nine quarter hours and one huddred fiftysix points as of larch, 1947.

Placement Test scores which "D" made range from .07 in Mathematics to .76 on the sychologica]. Total. Scores in Mathematics, Science and Iiterature were bel twenty-five, while Psychological Total and iffectiveness of expression scores are about fifty. on the Sophomore Comprehensive damination, taken before "D" left for the Army, he did not pass in the Social sciences. A re-test in November, 1946, however, removed this deficiency. "D" discussed his academic problens quite freely and surmed them up briefly as follors: The College was not offering a B.S. degree in Economics (without a foreign language requirement) and he could not get interested in French. His going out for track in his Freshman year may have taken too much of his time. As for fallIng the second semester of Principles of Economics, he knew he was going into the Service right away and just did not bother with 1t. He now feels confident that his acaden c difflculties are all straightened out. On the Bell Adjustment Inventory, his scores were as follow: 


$\begin{array}{lll}\text { Home Iffe } & - & \text { Exoellent } \\ \text { Health } & - & \text { Average } \\ \text { Sooially } & - & \text { Average } \\ \text { Motionally } & - & \text { Average } \\ \text { Total Adjustment } & - & \text { Average }\end{array}$

\section{INDIVIDUAL "E"}

During the Spring Quarter, 1947, "E" made an A, two C's and a D in Psychology, Physics, Biology and German respectively, He has a total academic standing of ore hundred thirty-seven quarter hours and one hundred nine points. He has been in school three terms since his retum from Service, and in that tite he has earned ten points more than he has hours.

"E", an upper third graduate from St. Xavier High School, attenled the College four semesters before he left for the Army, and in not one of them did he made a "C" aver ge. There are no F's on his record, but one $B$ was earned in hisical Education.

Upon entering school, "E"elected a course for pro-lieds. For the first serrester, he nade D's in Social Science and Bnglish, and C's in Biology, themistry and hysical Education. During this semester he took the Strong Vocational Interest Test and showed interests sdmilar, for the most part, to thet of masioians and advertising wen, with secord interests similar to that of lawyers and author-journalists, His interests corresponding to that of physiclans ranked third along with that of architeots, real estate salesmen and life insurance salesmen. At the end of the first semester, he was put on prabation with a deflcit of sie points.

The second semester grades were a little better, improvement 
being in Social Soienoe, with a grade of $C$. He was continued on probation, with a total standing of thirty-one hours and twentytwo points.

The two semesters immediately ureceding his entering into the Service are somewhat worse as far as grades are concerned. "g" signed up for German, Introduction to Literature, rsychology and History of Civilization. In these he made $C, D, C$ and $D$ ressectively the first semester. His probation was continued, even though he was now fourteen and one half points behind. During his last semester he managed to carry atxteen hours, of which ten turned out to be $D$ and six $C$. By this time he had a total of fifty-nine hours and thirty-four points. During this semester, he took the Sophomore Comprehenxive Examination and passed all of them.

"E" served thirty-gix months in the A.A.F. Hedtcal Corps. Most of his work was in a laboratory. While in Service, he earned four hours credit in Bacteriology, in one of the Service Schools. In commenting on his Service experience, "E" said, "It gave me a more realistic attitude toward my work."

"E" states that after the war began, and before he left for Service, he lost interest in School. He still plang to go to led School, but first he wants to obtain his B.S. degree in Blology. It seems likely that his military experience has bolstered up whatever Interest he may have lacked in medicine before he left for the Service. on the Bell Adjustment Inventory he made the following scores:

$$
\text { Home - Average }
$$




\begin{tabular}{|c|c|c|}
\hline $\begin{array}{l}\text { Health } \\
\text { Soolally } \\
\text { Bnotionally }\end{array}$ & $\overline{-}$ & $\begin{array}{l}\text { Oood } \\
\text { Average } \\
\text { Average }\end{array}$ \\
\hline Total Adjustment & - & Average \\
\hline
\end{tabular}

INOIVIDUAL "F"

"F" gradusted one hundredth out of a three hundred five class at Hale High School, being in the upper third of the class. About two years before he graduated, he decided to become a doctor. Mccordingly, in September, 1939, he registered at the University of Louisville as a premedioal student. The scores rade on the placement Test ranged from .09 in Science to 95 in Foreign Ifterature. Scores in knglish, Reading, Social Studies, Fine Arts and Foreign Literature are above fifty. Wathematios soores were twenty-five, Sychological Total forty and Science nine.

Luring the first year, "w" managet to kesp a "C" average. he made $B^{\prime} s$ in inglish and Social Sciences and D's in Wath, second semegter Chemistry and second semester Biology. The Sophomore year ended with D's in Fysies and 'sychology and one B in Kistory of Civilization. A total acaderic standing of fifty hours and fifty-one points resulted in a warning note from the Executive Committee, $\nu_{u x-}$ Ing this year, "pl" pssed the Sophowore Comprehensive Examination with all scores over fifty.

In the semester just preceding military service, "F" registered for History and Khilosohy of Science, German, Political Scienoe, Organic Chenistry and Comparative Hertebrate Anatomy. He received a $B$ In Science, a D in German and F's in the other subjects. From an interview with "F", the following information was gained: 
"F" felt that he was too young to appreciate this work; furthermore, that he had to work (reported forty hours weekly on information blank) in a grocery store when he should have been studying. The third factor which seems important here is the correlation of low scores in Hath and Science on the Placement Tests with grades made in the same courses in College.

While in the Service, "F" was connected with the liedical Corps, part of the time as a laboratory technician in Africa and Southern France, After about three years, he returned to the United States to resurie his work in pre-Med. For two terms he struggled with Ned subjects and in that time earned three hours $C, s i x$ hours $D$ and five hours F credit.

At the beginning of the Fall cuarter, "F" changed his major to Soctology. He signed up for courses in Political Science, History and Sociology, earning $\$ 1 x$ hours $B$ anc nine hours $C$. During the winter Quarter, while continuing in these courses, "Fil earred another six hours $B$ and nine hours $C$. This leaves hin with a starding of one hundred thirty-eight quarter hours and one hundred ten points, still on probation but definitely an effective student, on the way up.

* Wen being interviewed, he evinced enthasiasm and pride in his work, and confldence thet hs change in major was his academic "salvation". "F" 3 " neighborhood surroundings may not heve been the best, but other than their influence to make hin choose to be a doctor even though poorly equipped for the task, their effect does not seem to have been deterrent. On the BeIl Adjustment Inventory, "F" scored as follows:

Howe - Exsellent 


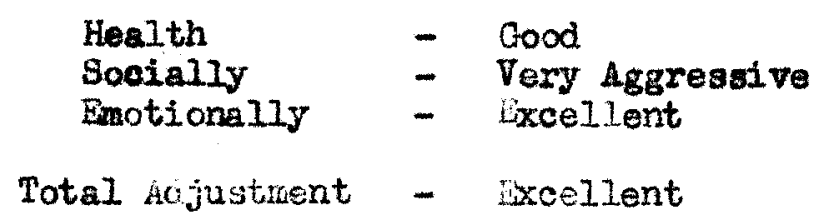

II. HIDLE THIRD HIOH SOHOCL GLADUATES ON HOBAIOA

Individual "G"

"G" is a middle third graduate of New Alb ny, Indiana, high School. There were over one hundred in the graduating cless. In choosing his life's work, he was at first hilluenced by his uncle to become a doctor. this plan was followed until he returned from the Sorvice.

Scores on the lacement Tests are extremely lar. It seams possible that eithor the instructi ns for taking the tests rere not anderstood, or that "ro" was not at his best when he took ther. His highsat score:was eight in Social Science, and there were several zeros.

In the first semester, "G" eamed C's in Chemistry, Biologr and hrysicsl ducation and $\mathrm{D}^{\prime}$ s in English and Social Scianco, ite was put on probation by the Fxecutive Conmittee. In the second semester, he race all C's. During the first semester of his So homore year, "Q" wh thdrow from school to enter the Army.

While in the Service, "G" served as a surgical technician. He remarked about the work that it dia not hike him the "eager beaver" he thought it would. Since his return, he decided to take up Law. is grades for the last tro quarters indicate that the change was for the better. In the first of these terms be earned fifteen hours and 
geventy and one half points.

Regarding the change of major, "G" remarked, "I oan't see myself studyling that hard for the reward I'd reap. I'm not a humanitarian." He considers his change of major as the important factor in tis academic progress.

\section{Individual "}

"H" was graduated middle third in his high school class at Newport, Kentucky. All but four of his Placement lest scores were above the fiftieth percentile. Psychological and Reading scores were forty-seven and forty-six respectively, and Foreign If teratiure and Ine Arts were each twenty-five. "H" also took the language test and was qualified to enter second year 3 anish because of high scores on his Placement Teat. He mas exempted from taking general education courses and from pasaing the sohomore Comprehensives. About the time he was six, "H" had decided he wanted to become a lawyer. His father is a college graduate wh legal training, but at the tire of "H's" entrance into collega, was emoloyed as a welder. Siace the mother and father were separated, father and son lived with an older sister and her family about fourteen miles out of Louisvilie.

When "H" was a Freshman, he felt that liring so far from school was responsible for his receiving twelve and one half hours $D$ and three madrs 0 during his first semester. He was put on probation. The fact that his parents were secarated mav have been more of a contributing factor. "H" suggested, in a recent interview, that at that tine he nas also worried about going into Service. He said he could not talk 
about "what hap sened in 1500 A.D. when we were at war in the twentioth century." During the second and last semester before his call to Service, "H" made eight and one half hours $C$ and six hours $D$ credit. For the year's work, he earned a total of thirty hours ant eleven and one half points, His probation was continuev.

Thile in Service, "H" served as a bombadier on a $\mathrm{B}-2$, in the Facific. Commenting on is experience, he aid that it did leave some bad impregsions. He learned that there was "more to life than living", and that "one should have a definite goa.1". Shortly before going overseas, "H" was narried, in February, 1944. Upon his return, he entered the University of Louigrille on probation. He has contimed his preLaw studies and has earned one A, four B's and seven C'g, His point standing has been bronght up almost to thet of a C. As of harch, 1947, "H" had ninety-one quarter hours and eighty-fite and one-fourth quarter points.

On the Bell Adjustment Inventory, "H" scored as follows:

$\begin{array}{ll}\text { Home Life } & - \text { Average } \\ \text { Health } & - \text { Unsatisfactory } \\ \text { Socially } & - \text { Aggreasive } \\ \text { Bmotionilly } & - \text { Usatisfactory }\end{array}$

Total Adjustment - Unsatisfactory

No other evidence of "l's" poor health is shom in his records. Since he has mace grect acadenic progress upon his return from Service, It is felt that adjustrents needed in other areas are taising place.

\section{Individual "I"}

"I" was voted "best oitizen" by sixty of his friends who graduated with him from Olendenin, West W1rginia high school, 1938. He ranked in the middle third of the groug and was very active in high school 
athletics. An only child whose mother was dead, "I" decided to follow his father's footsteps and become a doctor. On the Placement Tests, his highest scores were twenty-four for the fsychological and History Tests. Other scores ranged from eight in English to sixteen in Contemporary Affairs.

At elghteen, he entered the College of Arts and Sciences in September, 1938, and signed up for English, Social Jcience and Chemistry, Biology and hysical Education. At the end of the first semester, he had earned D, D, C, D and A respectively, with a total of fourteen and one half pours and five and one-half points. He was warned by the Executive Committee. At the end of the second semester, he had all $C^{\prime}$ s except for a D In Biology and an A in Physical Education. With a total of twenty-nine hours and seventeen points, he was placed on probation by the Executive Committee.

His Sophomore year, "I" signed up for Introduction to Literature, History of Civilization, thysics, Fsychology and advanced thysical Bducation, earning $C, C, D, D$, and B respectively. The following semester ended with C, F. W, C and D in these courses. During this semester, he took the Wophomore Comprehensive fxaminations and made seventy in History, fifty in Social science, fifty-five in Natural Science, twentylive in Humanities and forty-five in English. It is notable that these scores are considerably higher then corresponding scores made on the entrance examinations. IhIs may have been brought about by his becoming more familiar wh the objective type tests during his two years in college.

"I" returned to school in September, 1940, and earned four hours 
C, six hours $D$ and three hours $F$. His total academic standing sixtytwo hours, thirty-one points. He not dropped from school, but he did quit to go to work for a local firm manufacturing war materials. There he remained until drafted in 1942.

It seems that "I" was away from hore for the first time. His father, judging from correspondence in the records, s perhaps been a bit ober-anxious that his boy succeed in following in his footsteps. "I", at eighteen, was free to choose for himself. After five semesters of IIttle success, he quit school and went to work in Loulsville rather than return to West Virginia.

Upon entering the Service, "I" married a Lowisvillo girl and shortly afterwards was shlp ed overseas as a Surgical Technician. Commenting on life in the Service, "I" saic $h$ felt his experience did him "more good than harm". He now feels that when he was in school before he was too young to appreciate its value.

After discharge, "I" returned to enter school. In the four te rms since his return, his grades total three hours A, thirty-six hours B, fifteen hours $C$ and three hours $D$. lie is nom with $n$ five points of a total C average, and expects to graduate whth a B.S. degree in Biology in the surmer of 1947. This seems to be a oase where a boy just had to "grow up" away f rom home before he coild nake any academic progress.

on the Bell Adjustment Inventory, "I" shows the follonding tendenc109:

$\begin{array}{ll}\text { Hom Life } & \text { - Unsatisfactory } \\ \text { Health } & \text { - Arerage } \\ \text { Socially } & \text { - Retiring } \\ \text { Dotionally } & \text { - Very Unsatiafactory } \\ \text { Total Idjustment } & \text { - Very Unsatisfactory }\end{array}$


Howerer, it is belleved that he is making adjustments in his problems and w1l be able to graduate by the and of the sumrer.

III. LOWLE THIRD HIGH SOHOOL GRADUATES OFF PROBATION

Individual "J"

"As a first half Freshman, I did not aply myself as I now realize must be done to be a good college student. Wy second and third college semesters were spent under the Navy's V-12 program. The burden of carrying nineteen hours plus tho mentel reservations that I wasn't taking an active part in the world struggle was enough to lower grades and health. 1y last weeks in school were spent, not in studying for exams, but in a Navy siak bay."

The above paragraph was copted from the petition of "J", asking permission to re-enter the College after his term of lilitary Service. Since he was permitted to re-enter, he has proved conclusively that he was capable of college work, regardless of the fact that he graduated in the lower third at Male High School and that all but two scores on the Fresiman Tests were below the trenty-fifth percentile. Luring the three terms since his return, he has earned four hours A, twenty-two hours $B$ and eight hours $C$ towand his Dental School entrance requirements. His present acadome is one hundred nine hours, one hundred elghteen pointa-comfortable above the "C" average. He has exased a deficit of twenty-three points in this time.

"J" entered the College in 1943 at the age of elghteen. H1s first semestencourses inoluded the usual prescribed curriaulum for pre-dental students. His grades for the first semester were C's in Soolal Science and Fhysioal Education, and D's in English, Chemistry and Blology. At the ond of the semester, he entered the $\mathrm{N}_{2} \mathrm{val}$ College Training Program, 
then in operation on the Campus, and substituted a five hour Hath course and a one hour course in Naval organization for Social Science. Grades for this semester included two hours B, eight hours C and nine hours D. The Executive Committee then put him on probation, with an academic standing of thirty-three hours and seventeen and one-half points. The third semester's nineteen hour load proved almost too much for him. Unable to make a "G" tverage, "J" was transferred to sea duty by the Navy.

"J" had hoped that sea duty would give him a chance to be a Pharmacist's mate, but instead he received general duty assigmments on several Facific islands for flfteen months. This, he sald, was of no value for his school work.

Since "J" retumed toschool, he has continued with ids pre-dental course with great success. In his Psychology class, he feels that he has been able to see through his $\mathbf{p}$ oblems and take steps to correct then.

In an interview, he remarked that now he realized that his parents had his ow best interests at heart when they "foroed him to study". He had decided that he was too young for college work when he started and thathe had been an "orer-protected child". HIs eoores on the Bell Adjustment Inventory, which seem to agree with this analyais, are as follows:

$$
\begin{aligned}
& \text { Hone Iffe - Unsatisfactory } \\
& \text { Health - Average } \\
& \text { Socially - Very Aggresgive } \\
& \text { Enotiona11y - Average } \\
& \text { Total Adjustment - Average }
\end{aligned}
$$


"J's" scholastio success is exceptional in view of his high school rank and Freshmen Tast Scores. liaturity of purpe eand accurate self-analysis must certainly have been the redeeming factors.

\section{Individual "K"}

"K" graduated in the lower third of his class at lale High Sohool in 1942. His rocats onal plans at that time were to becom a chemist after graduating from the University of Louisville. Accordingly, he took the Freshman Tests and registered for classes in the Fall of that year. Scores on the tests range from four on Scienoe to eighty-four on the Iinguistio Aptitude section of the isychological Examination. Scores above fifty were made in Soientifie Aptitude, Linguistic Aptitude, Fsychologlal Total, History, Science, Mathematies and Total General oulture. It should be noted that the linguistic atitude scores was higher than thatfor scientific, and that knowledge about Science was the lowest score made on the entine test.

For the first semester, "I" elected Inglish Composition, Social Science, German, Chemistry and Physical Education. Orades for these coursed were $D, C, D, D$ and A respectively* This gave him a total of fourteen and one-half hours, seven and one-half points, and put him on probation. He taken into the $A r m y$ the end of this semester, where he served wits the Paratroopers for three and one half years. He was wounded twice in making serenteen fumps - three in combat. Since his return, he feels restless and finds it difficult to "settle down". However, in his three terms back, he has 
changed his major to Economics and earned six hours A, four hours $B$, twenty-one hours $C$, eight hours $D$ and two houra $F$. This has given him a total academic standing of on hundred six quarter hours, one hundred thirteen points.

In commenting about his work, "If" remarked that his experience In service was a maturing influence; that before the war he was too young for school, and thathe was working outside also. He thinks he understands his interests better now and that the change of major was really what was needed. On the Bell Adjustment Inventory, he showed the following tendenoles:

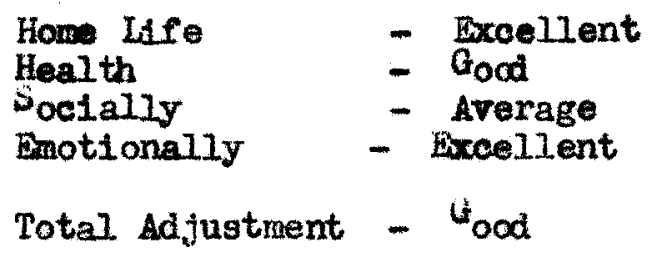

Individual "L"

"L" intends to become a Social Worker. He decided upon this two years before he graduated in the lower third of his class at lale High School. While in High School, he worked at the Y. M. C. A. and, as counselor in boy's camps, had had various contacts which acqualnted him with that type of work. He took the Freshmen Tests preparatory to registering in September, 1941, and mede several good scores. Above the fiftieth percentile were Inglish Mochanics, Current Sociel Problems, History and Soclal Solence, Fine Arts and Solence. Scores below the twenty-fith percentile were in English Ex,ression, Reading and Inglish Total.

For the first semester, "L" made "C's" in English composition, 
Introduction to Natural Science, American History and Thiloso,hy, and D's in American Covernment and Physical Education. He was put on probation by action of the Executive Committee at the end of that term. The second semester grades included C's in English CompositIon, Natural Science, rinciples of Economics, and $\mathrm{B}$ in Fhysical bducation, $F$ in Introduction to Sociology. This gre him a total academic standing of twenty-four hours, eighteen points. His probation was continued. The Sophomore year grades were three $D^{\prime} s$, two $C^{\prime} s$ the first Senester, and four C's the second, leaving a total of fifty hours and thirty-five points.

At fifteen points belw a $C$ average, "L" left school to enter the Navy. He was "washed out" of Naval Aviation Pllot Training frogram and was made an instructor in instrument flying. In 8ervice three and one half years, "L" commented that he liked the work and the people. He expressed feeling that his poor work beforemilitary training was due to "lack of interest", "not suffioient maturity", and full time work outside of class hours".

He $h$ a part time job now, but in the three terms since his return, it apparently has had no 111 effects. During this time, "L" has earned twentiy-one hours $B$ and twenty-one hours $C$. His academic standing as of Warch, 147, is one hundred seventeen guarter hours and one hundred fifteen points. On the Bell Adjustment Inventary, he records the following characteriatics:

$$
\begin{array}{ll}
\text { Hom Life } & - \text { Average } \\
\text { Health } & - \text { Average } \\
\text { Soclally } & - \text { Average } \\
\text { Bmotlonally } & - \text { Oood } \\
\text { Total Adjustment } & - \text { Average }
\end{array}
$$


Lost of the students in groups I and II are working toward a "C" average at good speed, of the six upper third students, two will probsbly be off probation by the end of the Spring Quarter, 1947 . All three middle third graduates will probably be off probation b y that time, likewise. It is notable that several of the st dents seem to have the same ideas about why they were not successful students before the War and why they are or are not successful now. Table XVII show the frequency of each reason expressed for difficulty before the War and of each reason for success after the War.

From the above Interviews, it seems that most of these students feel thatthey are making progress toward sohieving academic success. "Worry about going to war" is the most often mentioned reason for pre-war scholastic difficulties, wh "lack of interest" and "lack of maturity" tying for second in frequency. Three of the twelve mentioned outside work, but they also mentioned some of the other three factors. Factors contributing to post-war academic success of these twelve are first, a so-called "attainment of maturity", and second, a "change of major or occupational interest". One factor mentioned twice as deterrent tos uccese pertains to a physical handicap", either Service-connected or otherwise. These two studetits may never be completely successful until they have overeom their handicaps.

In order to se more clearly the probleas facing or overcome by anch individual, Table XVIII has boan devised First, the individual cas is listed, followed by his academic standing as of March, 1947. Last are given his reasons for difficulties before the war and 
TABLE XVII

FELQUENCY OF FACTORS WENTIONED IN INTERVIEWS AS AIDING OR RE-

TARDING ACADEMIC FROGRESS, BOTH BEFORE ARD AFTLE UILITARY SERVICE.

REASONS

BEFORE

UILITARY SERVICE
AFTER

WILITARY SURVIOE

WAR

LACK OF MATURITY

7

5

ATRAIMWNT OF DATURITY

4

PHYSICAL

2

FRATERMITY

1

OUTSIDE WORK

3

MAJOI CHANGE

1.

4

LACK OF INTESET

5

HOUE LIFE

1

OTHERS

1 
SUMMARY OF CAUSES FOR ACADDUIC DIFICULTY OR SUCCESS LENIONED BY TWELVE PROBATION STUDENS IN INTERVIEWS, MITE TOTLL ACADKUTC STANDTHG AS OF MALU:, 1947.

\begin{tabular}{|c|c|c|c|}
\hline INDIVIDUAL & $\begin{array}{l}\text { HOUR-POTNT } \\
\text { STANDING }\end{array}$ & $\begin{array}{l}\text { REASONS FOR LIFFIC } \\
\text { BEFORE SERICE }\end{array}$ & $\begin{array}{l}\text { WIY OE SUCCESS } \\
\text { AFTKR SERVICE }\end{array}$ \\
\hline A & $76 \%-32 \frac{2}{2}$ & War worry, too young & Physical defects \\
\hline B & $100-70_{2}^{2}$ & Fratemity, war worry & Getting married, health \\
\hline 0 & $24 \frac{2}{2}-30$ & $\begin{array}{l}\text { Didn't know withdrawal } \\
\text { rules. }\end{array}$ & Change of major \\
\hline D & $169-156$ & $\begin{array}{l}\text { Didn't want a foreign } \\
\text { language }\end{array}$ & $\begin{array}{l}\text { Changed to B.S, major } \\
\text { in Economics }\end{array}$ \\
\hline $\mathrm{E}$ & $137-1093$ & War worry & War matured his interests \\
\hline$F$ & $138-110$ & $\begin{array}{l}\text { Excess outside work, } \\
\text { Low soience aptitude. }\end{array}$ & Change of major \\
\hline G & $76 x-70 \frac{1}{3}$ & $\begin{array}{l}\text { Laik of interest in } \\
\text { family-imposed vocation- } \\
\text { al choices }\end{array}$ & Change of major \\
\hline $\mathrm{H}$ & $91-85$ & home life, war worry & $\begin{array}{l}\text { Haking pogress now. } \\
\text { Hore nature }\end{array}$ \\
\hline$I$ & $168-163$ & $\begin{array}{l}\text { Too young - not adjus- } \\
\text { ted to college life. }\end{array}$ & $\begin{array}{l}\text { Hore mature and bet- } \\
\text { ter adjusted. }\end{array}$ \\
\hline$J$ & $199-110$ & $\begin{array}{l}\text { Too young, "over protec- } \\
\text { ted," foreed to study, } \\
\text { war worry. }\end{array}$ & $\begin{array}{l}\text { Wore mature. Gained in- } \\
\text { signt into problems }\end{array}$ \\
\hline $\mathbf{K}$ & $106-113$ & 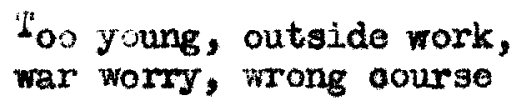 & Ohange of major \\
\hline L & $117-115$ & $\begin{array}{l}\text { Lack of interest and ma- } \\
\text { turity. Outsice wolk }\end{array}$ & $\begin{array}{l}\text { wore mature and only } \\
\text { part tiwe work }\end{array}$ \\
\hline
\end{tabular}


reasons for difficulty or success after the war. From this table seems to cone evidence that upper thi high school graduates either get farther behind in quality points or have more diffloulty regaining points they may have lost than do the middle third group. of course, that statement may be challenged because the middle third group of probation students are represented in interviews by but tirenty-five pereent of thelr group. Furthermore, certain factors beyond the control of the individual may be in existence now which were not present before the war - for example, the physical handicaps of two of the upper third group.

In sumary, it may be aid that freedom from worry about the War and the attainment of a more mature outlook on life are responsible largely for the success, or aproaching success, of the group Interviewed. The only factor retarding the progress of these twelve, regardless of high school rank and test scores, since their return from Service, was that of health. The two who gave health reasons for post-war failure were the only two of the group who gave indications of doubt regarding their uItinate academic success. The reports of these interviews seem to indicate that, given a fair chance and a reasonsble length of time, almost all of the group will a chieve academic success. 
$=$ 
OHAPTER VI

In this study of the veteran probation student, certain points already mentioned are notable. The fact that of the seventy-five students in the group, eighty-two per cent are from Loulsvilie and Jefferson County, Kentucky, seems to indicate that, at least among the probation students, the University's services are being utilized by students who live with their fam111es. Interesting is the fact that, in this particular group the upper and middle third high sohool graduates chose medicine or dentistry, the middle and lower third group chose lam, and that interest in economics and accounting seems to bo more or less evenly divided among all three. These three occupational groups represented eighty-two percent of the entire group. When It comes to rank in high school, the veteran probation student in this study is as likely to have graduated in upper as in the lower third of his class.

Although the policy regarding poor scholarship in the colloge must remain flexible, fifty-two percent of the probation group were judged before the war according to standards now in force, and thirty-seren per cent more recelved even greater scholastio leniency. Inis would leave only about ten per cent whose records were judged by higher standards than those imposed upon presently enrolled students. Fifty-three per cent of the group were put on probation after 
their first term in college. By the end of the second term, a total of seventy-five per cent were on probation. Since theis retirn from Service, over fifty per cent of the probation group are now off probation, twenty-eight per cent have droped to even lower scholastic levels and will likely never be able to attain a $c$ average in time to graduate or transfer to a professional school. This leaves a group of twent -one per cont, most of whom if given plenty of time and leniency, will eventually regain a "C" average.

Concerning afe as a factor in scholastic success, twenty-one wer cent of the total groug are under twenty-three and are still on urobation. About twenty-three percent are between twenty-three and twenty-five and are on probation. Blve per cent of the group are over twenty-five and are still on probation. It seans that the older students are doing better work than the growp of younger studeite, with those between the ages of twenty-three and twenty-five about equally divided between guccessful and unsucoessful.

Another factor in college success for the frobation student has been the change of majos or occupational interest. Thirteen yer cent of the total group desired pre-medical work before the war, but since their return, have changed to other courses. Twenty-nine per cent of the total group remain as pre-medical students. Before the war, fourteen cer ont the group desired to major in economics and accounting. Now thirty-one per cent are pursuing this course. Interest in education and pychology are claining a few of the pro bation group not originally planning for that major. As of March, 1947, however, twenty-nine per cent of those who changed their vocational objeative were still on probation. 
Test scores and high school rank seem to be important faotors In the success of these veteran probation students. Although the number remaining on probation in warch, 1947, was rather evenly divided between upper, middle and 10 wer third bigh sohool graduates, it was found that good scores on both the Psychological and Reading Tests helped the higher ranking studenta to pull away from probation. The Psychological score seemed more reliable in determining the scholastic progress of the lorer third probation student. The chances for sholastic success of probation students are liated as follows, When they ranked in the uppere and middle third of their graduating elass and made over flfty on both the Reading and Psychological Tests, their chances seemed to be nine to twelve and ten to thirteen respectively. If they wre in the lower thard of their graduating class and made over fifty on the Tests, their chances for success are four to s1x. On the other hand, if the student graduated in the upper or middle third of his class and made less than twenty-fire on both Tests, his chances for academic suocess to be eight to sixteen and four to fourteen, respectively. If he graduated in the lower third and de under twenty-five on the Tests, his chances are three in eight. This seems to indicate that both test scores and high achool rank are important determinants in predicting the veteran probation student's chances of getting off probation, upon his return from Service.

It was learned from interviening twelve of the students remaining on probation that, except in a case or two, they foel they are making progress and w11l eventually come up to a "G" average. 
They blane most of their st academic failure upon tre fact that they were"worried about going to war". S econd In frequency, they mentioned that their past fallure was due to "lack of maturity", that "they didn't know what they wanted." Three of the twelve mentioned "too much outside work" as cause of failure. Two factors seem especially important in contributing to these veterans postwar academio success. One is the somalled attaiment of maturity", and the other most frequently mentioned is a change of mior or vocational objective. One deterrent factor mentioned by tio so far unalecessful probation gtudents was that of health or phyacal disability. These interviews have brought to light certain factos in addition to high school rank and test soores which are of great Importance in the academic success of the veteran probation student.

A large group of the lower third students remain on progation and never bring their scholastic average to a "C". Their chanes for success are slight and their experience in college may not be as meaningful for them as it would be for others. However, some students in the lower third group do make the necessary adjustments to college life and achieve success. Since factors such as health, maturity and rocational interests are operative in this group, no successful measure as yet been devised to separate the potentially suocessful from the unsuccessful student.

Three of the original group of sevent,-five have received Bachelor's degrees, and three more are eligible to graduate at the next commencement. Undoubtedly, the veterans in this study are a purposeful group and, fiven plenty of time and eneouragement, most of then will reallze great benefits frothelr college experience. 
BIBLIOCRAPHI 


\section{BIBLIOGRAPHY}

\section{A. Books}

Abelson, H. H., The Art of EducatLonal Desearch. World Book Compeny. Yonkers on the Fudson, N. Y. 1933. 332 pg.

Cole, Imella, The Beckground fa College Teaching. Farrar and Rinehart, New York. 1940. $616 \mathrm{pp}$.

Emo , B. E., The Adjustment Probleme of College Freshnon. Cokesbury Preas, Nashvilie, Tenn. 1938. 125 pp.

Heaton and Veedon, the Falling Student. University of Chicago Prass. Chicago. 1939. 266 pp.

Litoyd-Jones, Eather, A Student Personnel Program for Higher Education, HcCraw Hill Company. Now York. 1938, 322 pp. Wel, Alice, Changing the Curriculum. D. Appleton-Century Company, Inc. New Tork. 1946. $242 \mathrm{pp}$. 


\section{B. Lagaine Articles}

Bent, R. K., "Scholastic Records of Non-High School Graduates Entering the University of Arkansas," Journal of Educational Research. 40:108-15. October, 1946 .

Blackwell, E. D., "An Evaluation of the Irmediate Effectiveness of the Testing and Chidance Bureau of the University of Texas," Journal of Educational Research. 40:302-8. December, 1946.

Humphreys, J. A., "Problems of Personnel Serrice and the Veteran," Journal of the American Association of Colleglate Registrars. Vo1. XXII. No. 3. April, 1947.

Scroggs, S., "College for All," Journal of Higher Education. November, 1946 .

Votaw, D. F., "A Comparison of Test Scores of Entering College Freshmen as Instruments for Predicting Subsequent Scholarship", Journal of Educational Research. 40:215-18. November, 1946 .

Welborn, E. L., "The Scholarship of Veterans Attending a Teachers' College," Journal of Educational Research. 40: 209-15. November, 1946. 


\section{c. Buletins}

Bulletin of the College of Arts and Sciences, Univereity of Loufavilie. Vol. Xl. No. 3

\section{Dissertations}

Carnett, R. L., Some Factors in College Success. Unpubllshed Doctoral Thesis. University of Missourl, Columbia, Malssouri. 1934. $65 \mathrm{pp} *$

\section{E. Testa}

Amertcan Council on Educational Paychological Examination. Thurston and Thurston. The American Council on Education. 74 . Jackson Place, Washi gton, D. C.

Co-operative English Examination. Davls and Others. Co-operative Test Service, 15 Ansterdam Avenue, New York City, N. Y.

Co-operative General Culture Tegt. Chesire, Townsend, and Others. Co-operative Test Service, 15 Amsterdam Avenue, New York City, N. Y.

Use of Library and Study Materials Test. Kilpatriok and Others, The Steck Company, Austin, Texas*

The Adjugtment Inventary Hugh M. Bell. Stanford Univeraity Fress. Stanford University, Californta. 